\title{
PERSPECTIVA TEOLÓGICA: MEMÓRIA, IDENTIDADE E FRONTEIRAS. ESTUDO BIBLIOMÉTRICO E SOCIOMÉTRICO DA PRODUÇÃo CIENTÍFICA DE 1969 A 2019.1
}

Perspectiva Teológica: Memory, Identity and Borders: Bibliometric and Sociometric Study of the Scientific Production on "Perspectiva Teológica" Journal from 1969 to 2019.1

\author{
Alex Villas Boas ${ }^{1}$ \\ Andréia Cristina Serrato ${ }^{2}$ \\ Alaís Daiane Zdziarski \\ June Alisson Westarb Cruz ${ }^{3}$
}

RESUMO: O presente artigo apresenta um resultado parcial do projeto de pesquisa de Mapeamento da produção da Área de Ciências da Religião e Teologia no Brasil, que diz respeito mais precisamente a análise do desempenho da Perspectiva Teológica, periódico ligado ao Programa de Pós-Graduação em Teologia da Faculdade Jesuíta de Filosofia e Teologia (FAJE), que celebra 50 anos e que iniciou a sua produção científica em 1969. Este artigo busca identificar as principais características e temáticas dos dossiês das publicações da revista, contemplando os autores, edições, temáticas dos dossiês e cooperação entre os autores. Por intermédio da série histórica de 1969 a 2019 (1ª edição), o periódico apresenta um total de 142 edições e um total de 594 artigos publicados. Para a análise utilizou-se a análise bibliométrica e análise de redes sociais. Como resultado, identifica-se as temáticas dos dossiês trabalhados no periódico, bem como as outras características de publicações. Ademais, com relação ao mapeamento dos elos relacionais entre autores, e seus respectivos índices de densidade, pode-se identificar duas tendências con-

\footnotetext{
${ }^{1}$ Universidade Católica Portuguesa, Lisboa, Portugal. Pontifícia Universidade Católica do Paraná, Curitiba, Paraná, Brasil.

2 Pontifícia Universidade Católica do Paraná, Curitiba, Paraná, Brasil.

${ }^{3}$ Pontifícia Universidade Católica do Paraná, Curitiba, Paraná, Brasil.
} 
solidadas como características históricas do perfil editorial do periódico, a saber a fronteira de temas da atualidade e eclesiologia.

PALAVRAS-CHAVE: Ciências da Religião e Teologia. Temáticas de Dossiês. Bibliometria. Sociometria. Redes Sociais. Mapeamento de Área.

ABSTRACT: This article presents a partial result of the research project of production of mapping research in the field of Religion Studies and Theology in Brazil. The specific objective is to analyze the performance and achievements of Perspectiva Teológica, a theological journal of the Graduate Program of Faculdade Jesuita de Filosofia e Teologia (FAJE). This journal started its scientific inquiries in the field of theology in 1969. This paper seeks to identify the main characteristics and themes, which emerged in the different dossiers or articles in the publications of Perspectiva Teológica in order to remember or value the authors, editions, themes of dossiers and cooperation among different authors. Revisiting the historical series of is publications from 1969 to 2019 (1st edition), the journal presents a total of 142 editions and a total of 594 published articles. The bibliometric analysis and social-networking analysis were utilized in this inquiry. As a result, many themes and other characteristics of different dossiers were identified in the different publications since the beginning of the existence of Perspectiva Teológica. Moreover, in relation to mapping of the links between authors and the respective substance of the subjects, there are two identifiable tendencies, which are consolidated as the historical characteristics of the journal's editorial profile, namely knowing or studying the frontier of current issues and ecclesiology.

KEYWORDS: Religion Studies and Theology. Themes of Dossier. Bibliometrics. Sociometry. Social Networks. Area Mapping.

\section{Introdução}

Deriódicos científicos são veículos de divulgação científica de grande 1 importância para a ciência moderna e contemporânea, pois permite a troca dos resultados de pesquisa entre os pares da comunidade acadêmica. O primeiro periódico científico foi criado em 1665 em Paris, chamado Journal de Sçavants pela Académie des inscriptions et belles-lettres, fundada em 1663 e após dois meses de criação da atual Journal des Savants, a Royal Society of London for Improving Natural Knowledge, criada em 1660, também lançava em março de 1665 a Philosophical Transactions of the Royal Society, ambas ainda em atividade. A finalidade do periódico científico, publicado em forma de panfleto, consistia em publicar notícias científicas e assim, socializar a prática de troca de resultados de pesquisa por cartas entre os pesquisadores, melhor atendendo, assim, as associações que iam se formando. O periódico assim, é um instrumento e um sinal da compreensão que ia se avolumando de que a ciência é uma atividade comunitária. Ademais, além de proporcionar a divulgação do conhecimento científico por meio da publicação dos resultados de pesquisas originais de uma comunidade 
acadêmica, constituem também uma "memória coletiva" de uma área de conhecimento (STUMPF, 1996), dimensão essa necessária para seu estabelecimento e consolidação, ajudando identificar o "estágio de desenvolvimento da área científica", e o nível de engajamento na atividade de pesquisa da comunidade (MIRANDA; PEREIRA, 1996, p. 376).

O presente artigo visa analisar o desempenho do periódico Perspectiva Teológica (PT), ligado ao Programa de Pós-Graduação em Teologia da Faculdade de Filosofia e Teologia da FAJE, como resultado parcial do Projeto de Pesquisa de Mapeamento da Área de Ciências da Religião e Teologia, pelo Grupo de Pesquisa em Teopatodiceia: Espiritualidade, Cultura e Práxis (CNPq), vinculado ao Programa de Pós-Graduação em Teologia e em parceria com o Programa de Pós-Graduação em Gestão de Cooperativas, ambos da Pontifícia Universidade Católica do Paraná (PUCPR). Tal parceria visa identificar a abrangência temática produzida e colaborar com a qualificação da cultura institucional presente na produção de conhecimento da área, ao oferecer visibilidade de desempenho e auxiliar na identificação de grandes tendências e possíveis lacunas diante dos desafios contemporâneos emergentes.

Nesta publicação o objeto de pesquisa é mapear a abrangência temática configuradora do perfil editorial do periódico, bem como seu desempenho em desenvolver trabalho em rede, identificada como ação conjunta de grupos, a fim de proporcionar uma "produção consolidada e orgânica acerca dos objetos de investigação", e um dos modos de medir a interdisciplinaridade da área, ao possibilitar identificar os núcleos temáticos, geradores de redes de investigação (KUHLMANN JR, 2014, p. 26).

Para atingir o objetivo deste projeto de pesquisa, se utilizou a aplicação do método bibliométrico, com ferramentas de sociograma para identificação da formação de redes de pesquisa que também atuam como redes sociais na área, bem como seu desempenho.

As variáveis são representadas pelos indicadores individuais de análise de redes sociais (variável independente), tais como: centralidade de grau; centralidade de intermediação; e centralidade de proximidade.

\section{Abordagem teórica: análise de redes e desempenho}

A área de Ciências da Religião e Teologia possui uma aparente inexistência de trabalhos publicados que adotam métodos bibliométricos, e por consequência, com possíveis leitores não familiarizados ${ }^{4}$. Para Van Aken e

\footnotetext{
${ }^{4}$ Em função da publicação parcial dos resultados do Projeto de Pesquisa de Mapeamento da Área de Ciências da Religião e Teologia, a parte metodológica do artigo poderá ser reutilizada em outros artigos destinados a outros periódicos, sofrendo adaptações de acordo com seu objetivo específico. A
} 
Weggeman (2000) e Cruz (2007), toda e qualquer organização ou individuo está envolvida em alguma forma de rede (temas nucleadores dos periódicos, número de autores que publicam no periódico, etc.), nesse sentido, alguns aspectos estruturais e gerenciais determinam a formação de redes no ambiente onde estão inseridos, podendo apresentar uma maior relação de densidade a partir do envolvimento dos atores. Powell e Smith-Doerr (1994), descrevem redes formadas pelos autores como um conjunto de relações entre atores, cujo conteúdo representa sua tipologia e forma sua intensidade de relacionamento. Granovetter e Swedberg (2001) descrevem rede como um grupo regular de contatos entre indivíduos ou organizações.

Com relação à análise de redes sociais sob uma perspectiva conceitual, esta pode ser considerada como uma metodologia aplicada ao estudo das relações entre atores com objetos de qualquer natureza (BORGATTI et al., 2002), que no presente caso, diz respeito a promoção de um espaço de divulgação que reúne especialistas de diversas áreas para disponibilizar o resultado de suas respectivas pesquisas a uma comunidade acadêmica, bem como o relacionamento entre os autores da área. A seguir são apresentadas algumas das principais tipologias de redes para análise:

a. Redes simétricas: são compostas por relacionamentos por atores com a mesma capacidade de influência (OLAVE; AMATO NETO, 2001);

b. Redes assimétricas: são caracterizadas pela presença de agentes centrais (OLAVE; AMATO NETO, 2001).

Esta distinção possibilita identificar quais e como temáticas e atores influenciam a comunidade acadêmica. Ademais, diante da apresentação inicial da abordagem conceitual de redes, algumas medidas de análise merecem especial atenção (CRUZ, 2012), dentre elas, segundo Lorrain e White (1971), destacam-se medidas como centralidade de grau, centralidade de proximidade, centralidade de intermediação, densidade, distância geodésica, entre outros, conforme apresentado a seguir:

a. Centralidade de grau (degree): demonstra o número de laços que um ator (nesse caso autores e temáticas) possui com outros atores em uma rede (FREEMAN, 1979). A centralidade de grau é calculada de forma relativa ao tamanho da rede, dividindo-se o número de ligações existentes, pelo número máximo de ligações possível ${ }^{5}$.

finalidade do reúso, respeitando assim, o percentual de até $30 \%$ de outro texto autoral em acordo com a Lei de Direitos autorais n.9.610, de 19 de fevereiro de 1998, é possibilitar que o leitor do artigo tenha uma leitura suficiente, sem ter que recorrer a outras publicações para os resultados sejam inteligíveis.

${ }^{5}$ Aplica-se a fórmula:

Centralide de grau $(i)=\frac{\text { número de ligações do ator } i}{n-1}$

Onde n é o número de atores na rede. 
b. Centralidade de proximidade (closeness): demonstra a distância de um ator em relação aos outros autores da rede (WASSERMAN; FAUST, 1994). É calculada pelo inverso do distanciamento de um ator em relação aos outros, somando-se a totalidade dos distanciamentos possíveis e divide-se pela quantidade de relações ${ }^{6}$;

c. Centralidade de intermediação (betweenness): demonstra a interação entre atores não adjacentes. Um ator é considerado um intermediário se ele liga vários outros atores que não se conectam diretamente (DEGENNE; FORSÉ, 1999). É calculada pelo total de pares de vértices possíveis, excluindo-se o próprio vértice analisado ${ }^{7}$;

d. Densidade: cálculo da proporção de linhas existentes em um gráfico, com relação ao máximo de linhas possíveis (SCOTT, 2000);

e. Distância geodésica: é a menor distância entre dois nós (WASSERMAN; FAUST, 1994).

Estes conceitos "são utilizados como fundamento para estudos cuja pretensão é estabelecer uma base de associação entre o posicionamento na rede com o comportamento ou uma medida de desempenho dos atores" (AIRES, 2016, p. 167), e ainda é colocado que essa pretensão de associação visa estabelecer com comportamento ou medida de desempenho dos autores, a saber autores e temáticas (CRUZ, et al, 2011). O método de análise de redes pode ser aplicável a qualquer assunto empírico, dando especial importância aos efeitos do comportamento de centralidade dos atores na rede e a natureza das relações entre indivíduos e organizações, sobre o seu comportamento estratégico e objetivos contemplados em séries temporais, possibilitando indicar a contribuição do periódico na comunidade acadêmica (MIZRUCHI, 2006).

Becker (2007) e Cruz et al (2013) destacam que o desenvolvimento das redes, como algo participativo gera um processo de amadurecimento e reflexão de seus atores, estabelecendo-se uma relação essencialmente dinâmica e evolutiva, sendo este o ambiente de reflexão, implementação e controle de

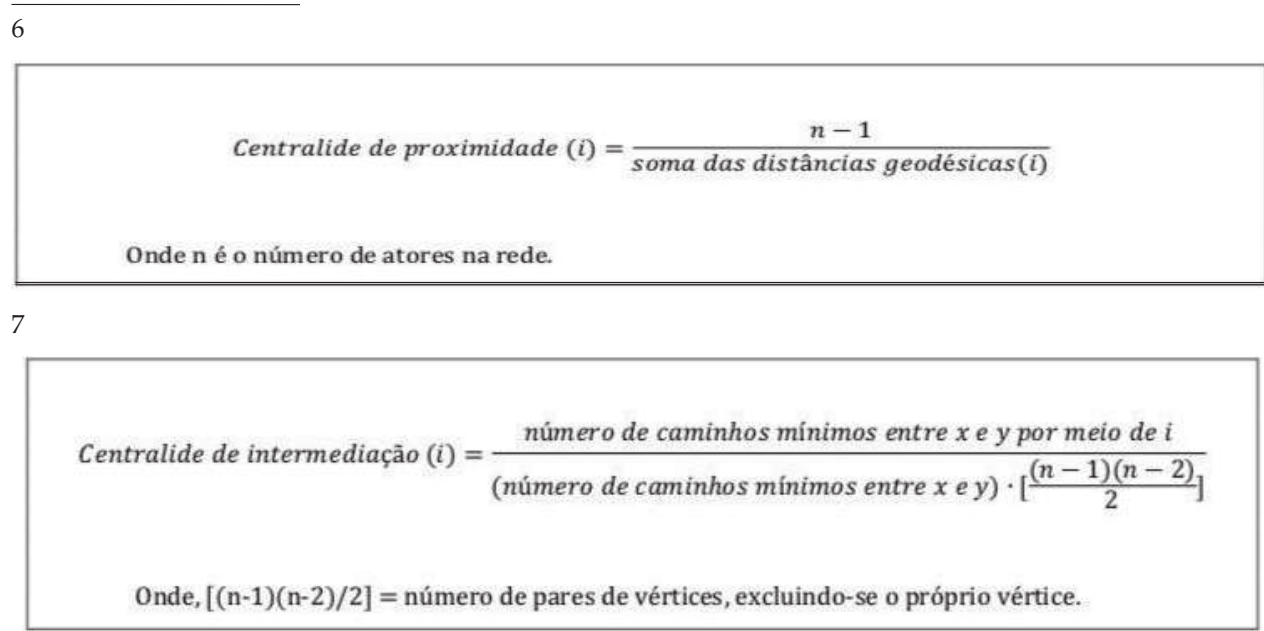


estratégias com foco em desempenho, no caso da comunidade acadêmica (CRUZ at al, 2008). Na medida em que se pode mapear as tendências de desempenho de um periódico científico, pode-se melhor identificar uma intencionalidade editorial, sua contribuição distintiva, assim como possibilitar o planejamento de ajustes editoriais.

Além da discussão da forma de desempenho e sua relevância no contexto específico dos atores de uma rede, especial destaque se dá à complexidade de mensuração da associação positiva entre a estrutura de redes e o pleno cumprimento dos objetivos dos integrantes da rede (CRUZ, et al, 2013), identificando assim, se há uma ampliação e/ou uma consolidação temática no desempenho do periódico, e em que medida, podendo ser prioritariamente medida por indicadores estruturais em séries temporais (MIZRUCHI, 2006).

\section{Procedimentos metodológicos}

A metodologia de pesquisa empregada no presente artigo é a pesquisa bibliográfica e bibliométrica. Esta opção metodológica é baseada no evidente crescimento dos estudos científicos, sobretudo os dossiês das revistas na área de Ciências da Religião e Teologia e sua forma de disseminação por meio da tecnologia da informação, ampliando assim a utilização do produto epistêmico clássico, a saber o livro impresso, e a qual vem constantemente criando novos canais de comunicação do saber e do conhecimento, provocando nas últimas décadas uma revolução na forma de se perceber a relação entre a produção do conhecimento, a pesquisa, suas formas de registro e a sua divulgação e abrangência (ROCHA, et al, 2013).

Diante de todo esse exponencial crescimento muito se tem discutido, especialmente as áreas ligadas à Ciência da Informação, sobre a importância e a relevância das temáticas dos dossiês a serem estudadas e sua disseminação para a sociedade acadêmica e em geral. Tem-se aprofundado os estudos para saber qual o real interesse da sociedade leitora deste conteúdo acadêmico, e mesmo a relevância que tal assunto possui para a sociedade em geral, bem como para os pesquisadores envolvidos e responsáveis pelas pesquisas, identificando ainda quais são as temáticas de dossiês mais pesquisadas e o grau de relacionamento dos autores.

Vale destacar, que a busca de compreensão do fenômeno e relevância da produção científica e sua disseminação não é algo novo. De acordo com Dos Santos e Kabashi "o uso de métodos estatísticos e matemáticos para mapear informações, a partir de registros bibliográficos e documentos (livros, artigos, periódicos) não constituem fato novo" (DOS SANTOS e KABASHI, 2009, p. 157). No Brasil os estudos bibliométricos se proliferaram a partir da década de 70 (ARAUJO, 2006). Entretanto, ainda é uma novidade o uso da bibliometria para mensuração da produção acadêmica 
da Área de Ciências da Religião e Teologia, podendo, talvez, associar essa lacuna a sua recente autonomia institucional, em 2016.

Atualmente estes estudos derivam da bibliografia estatística que segundo Campos (2003) foi um termo cunhado por Hulme em 1923, esse método de análise - bibliometria - surgiu no início do século XX a partir de estudos de Paul Otlet na década de trinta (VANTI, 2002; DOS SANTOS e KABASHI, 2009). Para Otlet (1934 apud DOS SANTOS e KABASHI, 2009) que descreve sobre a definição de bibliometria, como área que se ocupa da medida e da quantidade aplicada a produtos epistêmicos (livros, periódicos científicos, entre outros), ou seja, busca mensurar, monitorar e descrever como determinado material de conhecimento é difundido na sociedade. Vanti (2002, p. 155) descreve como sendo algumas das possiblidades de utilização da bibliometria, as quais são ressaltadas por Rocha. São elas:

a. identificar as tendências e o crescimento do conhecimento em uma fase;

b. identificar as revistas do núcleo de uma temática;

c. mensurar a cobertura das revistas secundárias;

d. prever tendências de publicação;

e. estudar a dispersão e a obsolescência da literatura;

f. prever a produtividade de autores individuais, organizações e países;

g. medir o grau e padrões de colaboração entre autores;

h. analisar os processos de citação e co-citação;

i. dentre outras (ROCHA et al, 2013, p. 36).

O presente trabalho se atém aos itens $a, b$, e $d$, porém, em função da proposta de fazer uma memória da área não se pretende "prever", mas identificar as tendências de publicação históricas. Também é possível medir o grau e os padrões de colaboração entre autores $(\mathrm{g})$.

A população da pesquisa incidiu sobre os artigos publicados no periódico PT, desde o seu surgimento até o corrente ano, que resulta em 50 anos da sua existência, sendo a segunda revista científica de teologia mais antiga do país ${ }^{8}$.

A coleta de dados ocorreu por meio de pesquisa de dados secundários, enquanto a perspectiva temporal compreende observações longitudinais. A obtenção das temáticas dos dossiês publicados revisados se deu por buscas eletrônicas realizadas nos endereços eletrônicos das revistas. Os dados coletados sobre as publicações incluem: títulos dos dossiês (formuladas as temáticas, englobando diversos títulos), artigos, ano de publicação e autores. Após a tabulação dos dados, procedeu-se à verificação da grafia dos dados e a padronização das temáticas dos dossiês afastando-se a

${ }^{8} \mathrm{O}$ primeiro periódico científico no Brasil é a Estudos Teológicos da EST, que assim passa a ser chamada em 1961, mas teve início com o nome de Studien und Berichten, em 1947. 
possibilidade de repetição de temáticas. Em função do volume de dados e dos limites do presente artigo, optou-se, por apresentar aqui a análise das temáticas dos dossiês.

Com relação à forma de análise dos dados, o estudo compreende duas formas distintas de análise: software de análise de redes sociais (Ucinet) e análise estatística descritiva. Por meio da geração de dados de análise de redes, tais como: densidade, centralidade de grau, centralidade de intermediação, centralidade de proximidade, entre outros. Por fim, foi feito o uso de sociogramas, a fim de evidenciar em formas de gráficos os núcleos e a capilaridade que um tema possui entre os periódicos da Área de Ciências da Religião e Teologia.

Para a realização da análise optou-se pela divisão em décadas, que possibilita mapear uma estruturação de uma tendência temática em uma séria temporal, escolhida aqui como década. Entretanto, para a última década, optou-se por considerar o período de avaliação quadrienal da CAPES, a partir da criação da área autônoma de Ciências da Religião e Teologia, em 2016. Com isso, a década de 2010-2019, foi fracionada a partir de P6 (2013-2016), que se desdobrou em P5 (2010-2012), um período de avaliação imediatamente anterior à autonomia da Área, e P7 (2017-2019), atual quadriênio de avaliação.

\section{Apresentação e análise de resultados}

A primeira publicação da revista Perspectiva Teológica foi em 1969, a qual apresenta-se com a seguinte missão:

Como finalidade divulgar a reflexão teológica (no âmbito sistemático, bíblico e pastoral) com qualidade científica reconhecida, estando aberta ao diálogo ecumênico e inter-religioso, bem como a outros campos do saber científico que contribuam para o serviço da fé e o compromisso com a justiça. Deste modo, constitui-se em instrumento a serviço da permanente atualização da teologia e esclarecimento da fé cristã frente aos problemas do mundo pós-moderno. Através de artigos temáticos e diversos oferece aos que se dedicam à teologia auxílio para sua reflexão e debate teológico. Possibilita a seus leitores (as) subsídios para fundamentar, ao longo do tempo, a razão de sua fé e esperança $(1 P d 3,15)$ (PERSPECTIVA TEOLÓGICA, 2019).

A revista busca incorporar e aculturar-se, devido ao fato que a revista PT publica artigos que abrangem as áreas: "1. Teologia da Práxis Cristã (Espiritualidade Cristã e Pluralismo Cultural e Religioso; Tendências Éticas Atuais). 2. Teologia Sistemática (Fontes Bíblicas da Tradição Cristã; Interpretação da Tradição Cristã no Horizonte Atual) " (PERSPECTIVA TEOLÓGICA, 2019). A revista estimula a participação de diversos pesquisadores, visando ampliar suas ramificações. 
A partir de tal contextualização, e considerando a relevância da revista na área da Teologia e Ciências da Religião, a seguir é apresentada a análise dos dados obtidos entre os períodos de 1969 a 2019 (1ª edição), atingindo assim 142 edições, nas quais foram publicados 594 artigos científicos.

\subsection{Perspectivas Temporais das Publicações}

No ano de 1969 a revista PT teve 1 publicação, contanto com 10 artigos. Entre os anos de 1970 a 1975 a revista teve 2 edições por ano, sendo um total de 12 edições no período, com um total de 73 artigos publicados. Entre os anos de 1976 a 1980 a revista publicou 3 edições por ano, totalizando 15 edições no período, publicando o total de 59 artigos. Já no ano de 1981 a revista publicou 2 edições, com um total de 6 artigos. Do ano de 1982 a 2018, a revista publicou 3 edições por ano, totalizando 111 edições neste período, e com a publicação de 438 artigos para o período. No ano de 2019, até o momento desta pesquisa, a revista publicou uma edição, com 8 artigos científicos.

Ao longo de sua existência a revista contou com 1 (uma) publicação em um dos anos, alguns anos com 2 (duas) publicações e os demais com 3 publicações (edições) anuais, totalizando ao longo de sua existência 142 edições, até o período estudado. $\mathrm{O}$ quadro a seguir, demonstra a série temporal dos artigos, conforme sua distribuição anual (para fins de visualização, por se tratar de um longo período da existência da revista, o quadro foi quebrado).

Quadro 1 - Total de Artigos e Edições analisados

\begin{tabular}{|c|c|c|c|c|c|c|c|c|c|c|c|c|c|c|c|c|c|}
\hline \multicolumn{18}{|c|}{ NÚMIERO DE ARTIGOS E EDIÇÕES PUBLICADOS POR ANO - REVISTA PERSPECTIVA TEOLÓGICA } \\
\hline ANO & 1969 & 1970 & 1971 & 1972 & 1973 & 1974 & 1975 & 1976 & 1977 & 1978 & 1979 & 1980 & 1981 & 1982 & 1983 & 1984 & 1985 \\
\hline ARTIGOS & 10 & 11 & 19 & 13 & 11 & 11 & 8 & 12 & 11 & 13 & 14 & 9 & 6 & 11 & 10 & 7 & 9 \\
\hline EDIÇÕES & 1 & 2 & 2 & 2 & 2 & 2 & 2 & 3 & 3 & 3 & 3 & 3 & 2 & 3 & 3 & 3 & 3 \\
\hline ANO & 1986 & 1987 & 1988 & 1989 & 1990 & 1991 & 1992 & 1993 & 1994 & 1995 & 1996 & 1997 & 1998 & 1999 & 2000 & 2001 & 2002 \\
\hline ARTIGOS & 10 & 9 & 9 & 10 & 11 & 12 & 9 & 11 & 11 & 12 & 8 & 9 & 8 & 7 & 9 & 9 & 9 \\
\hline EDIÇÕES & 3 & 3 & 3 & 3 & 3 & 3 & 3 & 3 & 3 & 3 & 3 & 3 & 3 & 3 & 3 & 3 & 3 \\
\hline ANO & 2003 & 2004 & 2005 & 2006 & 2007 & 2008 & 2009 & 2010 & 2011 & 2012 & 2013 & 2014 & 2015 & 2016 & 2017 & 2018 & 2019 \\
\hline ARTIGOS & 10 & 12 & 9 & 8 & 9 & 8 & 11 & 9 & 15 & 18 & 18 & 18 & 18 & 23 & 25 & 27 & 8 \\
\hline EDIÇÕES & 3 & 3 & 3 & 3 & 3 & 3 & 3 & 3 & 3 & 3 & 3 & 3 & 3 & 3 & 3 & 3 & 1 \\
\hline & & & & & & & 142 & & & & & & & & & 59 & \\
\hline
\end{tabular}

Fonte: Elaborado pelos autores, 2019.

O levantamento dos dados ainda identificou 276 autores, entre estes 7,25\% (20 autores), publicaram 6 ou mais artigos, o que representa $34,68 \%$ dos artigos publicados pela revista, 15 autores publicaram 5 ou 6 artigos, representando 10,77\% dos artigos, já 18 autores publicaram 3 artigos na revista, sendo 9,09\% dos artigos, ainda 47 autores publicaram 2 artigos, 
chegando a 15,82\% dos artigos, enquanto 176 autores publicaram 1 artigo cada, representando $29,63 \%$ dos artigos publicados pela revista e representa $63,77 \%$ dos autores. A tabela a seguir representa o corte relativo aos autores que publicaram 6 ou mais artigos na revista, indicando desta forma, nominalmente os autores, pelo número de artigos publicados na revista.

Tabela 1 - Relação de Autores com mais artigos na Revista Perspectiva Teológica

\begin{tabular}{|c|c|c|}
\hline \multicolumn{3}{|c|}{ AUTORES COM MAIS ARTIGOS NA REVISTA PERSPECTIVA } \\
\hline $\mathbf{N}^{\circ}$ & Autor & Artigos \\
\hline 1 & JOÃO BATISTA LIBÂNIO & 20 \\
\hline 2 & MARIO DE FRANÇA MIRANDA & 20 \\
\hline 3 & FRANCISCO DE ASSIS COSTA TABORDA & 17 \\
\hline 4 & VICTOR CODINA & 13 \\
\hline 5 & JUAN ANTONIO RUIZ DE GOPEGUI SANTOYO & 12 \\
\hline 6 & ALBERTO CASALEGNO & 11 \\
\hline 7 & CARLOS PALÁCIO & 11 \\
\hline 8 & FAUSTINO LUIZ COUTO TEIXEIRA & 11 \\
\hline 9 & JESUS HORTAL SÁNCHEZ & 11 \\
\hline 10 & JOHAN MARIA HERMAN JOZEF KONINGS & 11 \\
\hline 11 & CLÁUDIO LUIZ BINS & 8 \\
\hline 12 & LUÍS INÁCIO JOÃO STADELMANN & 8 \\
\hline 13 & MARIA CLARA LUCCHETTI BINGEMER & 8 \\
\hline 14 & FRANCISCO DE AQUINO JÚNIOR & 7 \\
\hline 15 & JOÃO BALDUINO KIPPER & 7 \\
\hline 16 & ULPIANO VÁRQUEZ MORO & 7 \\
\hline 17 & ÁLVARO BARREIRO Y LUAÑA & 6 \\
\hline 18 & BERNARDINO LEERS & 6 \\
\hline 19 & FELIX ALEJANDRO PASTOR PIÑEIRO & 6 \\
\hline 20 & RIOLANDO AZZI & 6 \\
\hline
\end{tabular}

Fonte: Elaborado pelos autores, 2019.

\subsection{Perfil dos Elos Relacionais da Rede}

Compreendidas as características bibliométricas da revista objeto de pesquisa em todo o seu período de 1969 a 2019 (1ª edição), cabe salientar a perspectiva relacional dos autores que publicaram na revista PT no período pesquisado (1969-2019 [1 $1^{a}$ edição]). Buscando evidenciar os elos relacionais dos autores, estes foram todos mapeados. Para que os dados fossem tratados e analisados, estes autores foram divididos nos seguintes períodos: MA1 - 1969-1979; MA2 - 1980-1989; MA3 - 1990-1999; MA4 - 2000-2009; MA5 - 2010-2012; MA6 - 2013; MA7 - 2017-2019 (1ํeㄹição). Os autores foram estruturados em uma matriz binária $(0$ e 1$)$, de acordo com a existência ou não de relações entre os autores. Segundo Abdalla et al (2014) "a densidade da rede é calculada pela proporção de linhas existentes em um gráfico, com relação ao máximo de linhas possíveis, podendo variar de 0 a 1" (ABDALLA et al, 2014, pg. 34), ainda segundo Abdalla (2014), a escolha dessa medida em o objetivo de evidenciar o padrão das densidades geral das relações nos períodos analisados. 
As figuras a seguir, divididas conforme determinado pelos autores (MA1 - 1969-1979; MA2 - 1980-1989; MA3 - 1990-1999; MA4 - 2000-2009; MA5 - 2010-2012; MA6 - 2013-2016; MA7 - 2017-2019 (1 ${ }^{a}$ edição)), foram identificados 276 autores em todos os períodos. Sendo as matrizes de análises divididas e analisadas da seguinte forma:

- MA1 - 1969-1979: foram identificados 69 autores, com uma densidade geral da rede de 0 , ou seja, neste recorte do mapeamento de autores não temos a formação de redes de relacionamento, o que indica que os autores não publicaram juntos (demonstrado na figura a seguir, quadrante P1);

- MA2 - 1980-1989: foram identificados 52 autores, com uma densidade geral da rede de 0,0362, identificando a existência de rede de relacionamento no período (demonstrado na figura a seguir, quadrante P2);

Figura 1 - Sociogramas Gerais das Rede MA1 - 1969-1979; MA2 - 1980-1989

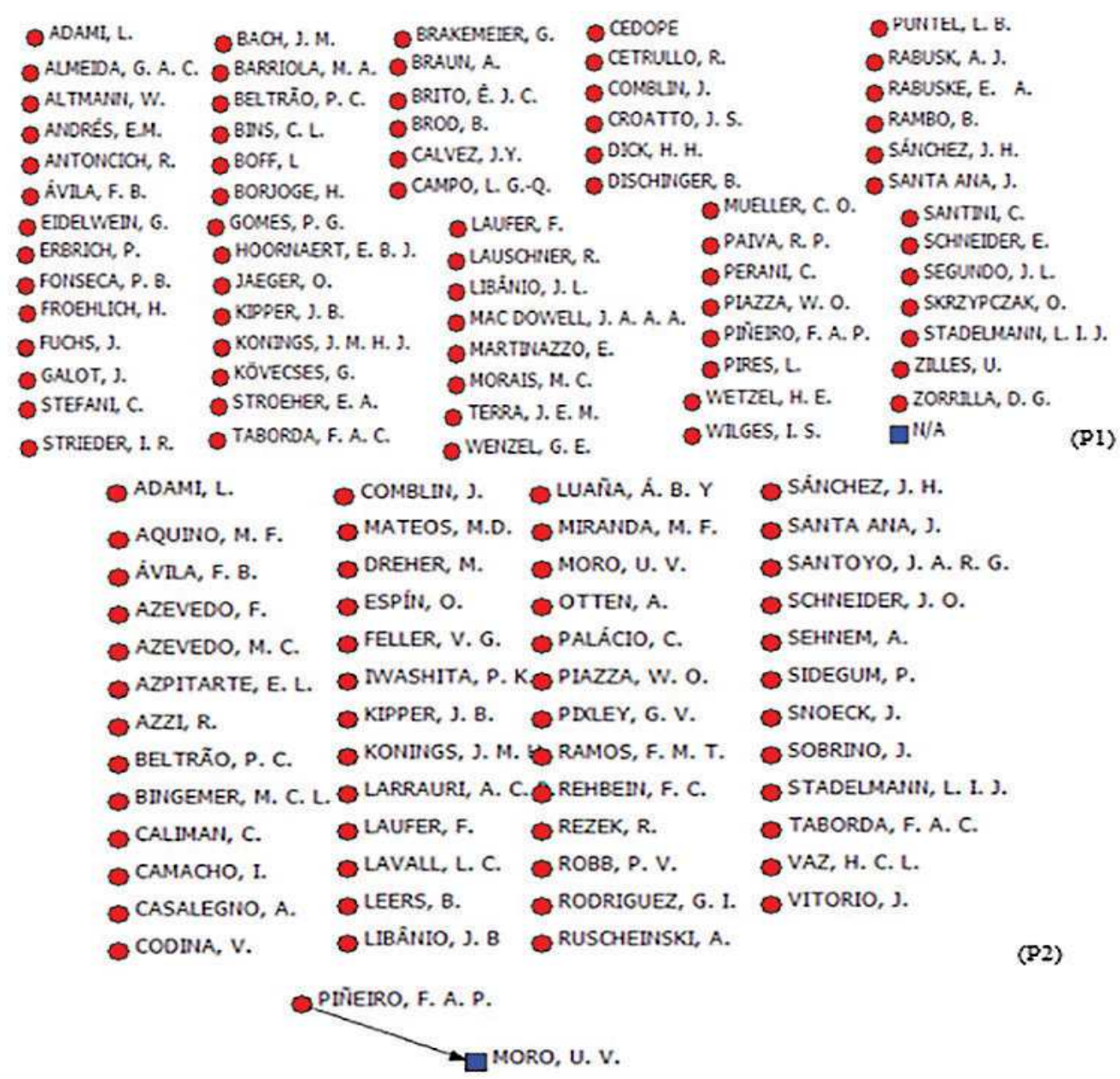

Fonte: Elaborado pelos autores, 2019. 
- MA3 - 1990-1999: foram identificados 46 autores, com uma densidade geral da rede de 0 , ou seja, neste recorte do mapeamento de autores não temos a formação de redes de relacionamento, o que indica que os autores não publicaram juntos (demonstrado na figura a seguir, quadrante P3);

- MA4 - 2000-2009: foram identificados 60 autores, com uma densidade geral da rede de 0,0528 , identificando a existência de rede de relacionamento no período (demonstrado na figura a seguir, quadrante P4);

Figura 2 - Sociogramas Gerais das Rede MA3 - 1990-1999; MA4 - 2000-2009

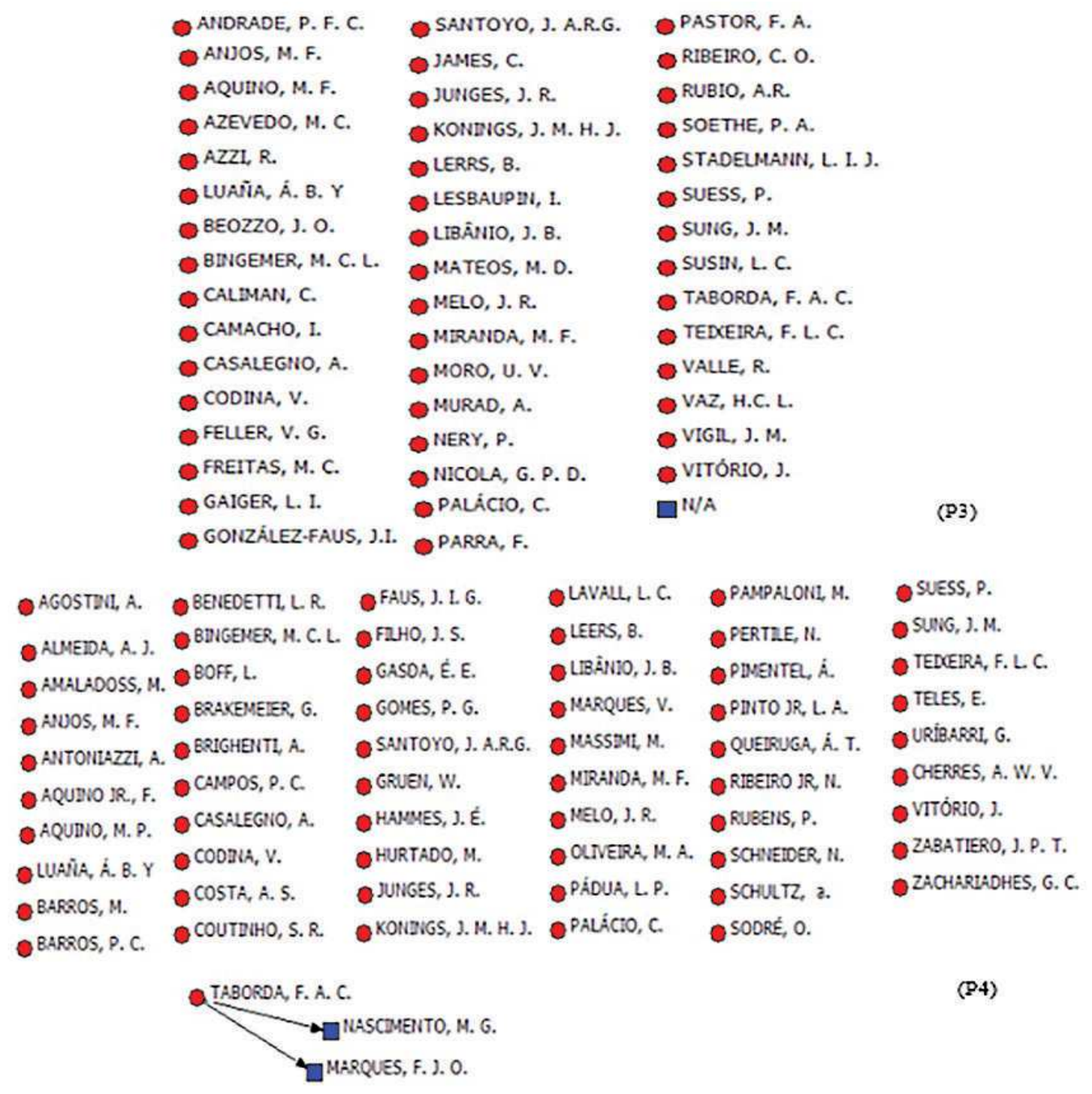

Fonte: Elaborado pelos autores, 2019.

- MA5 - 2010-2012: foram identificados 39 autores, com uma densidade geral da rede de 0,2214 , identificando a existência de rede de relacionamento no período (demonstrado na figura a seguir, quadrante P5);

- MA6 - 2013-2016: foram identificados 71 autores, com uma densidade geral da rede de 0,0877 , identificando a existência de rede de relacionamento no período (demonstrado na figura a seguir, quadrante P6); 
- MA7 - 2017-2019 (1 $1^{\underline{a}}$ edição): foram identificados 56 autores, com uma densidade geral da rede de 0,060, identificando a existência de rede de relacionamento no período (demonstrado na figura a seguir, quadrante P7);

Figura 3 - Sociogramas Gerais das Redes MA5 - 2010-2012; MA6 - 2013-2016; MA7 - 2017-2019 (1ª edição)

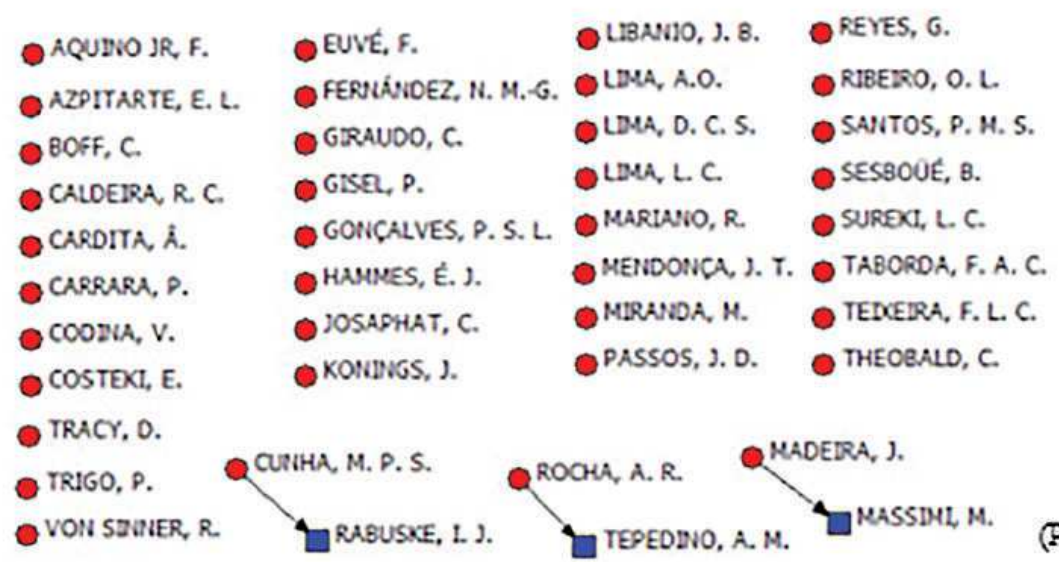

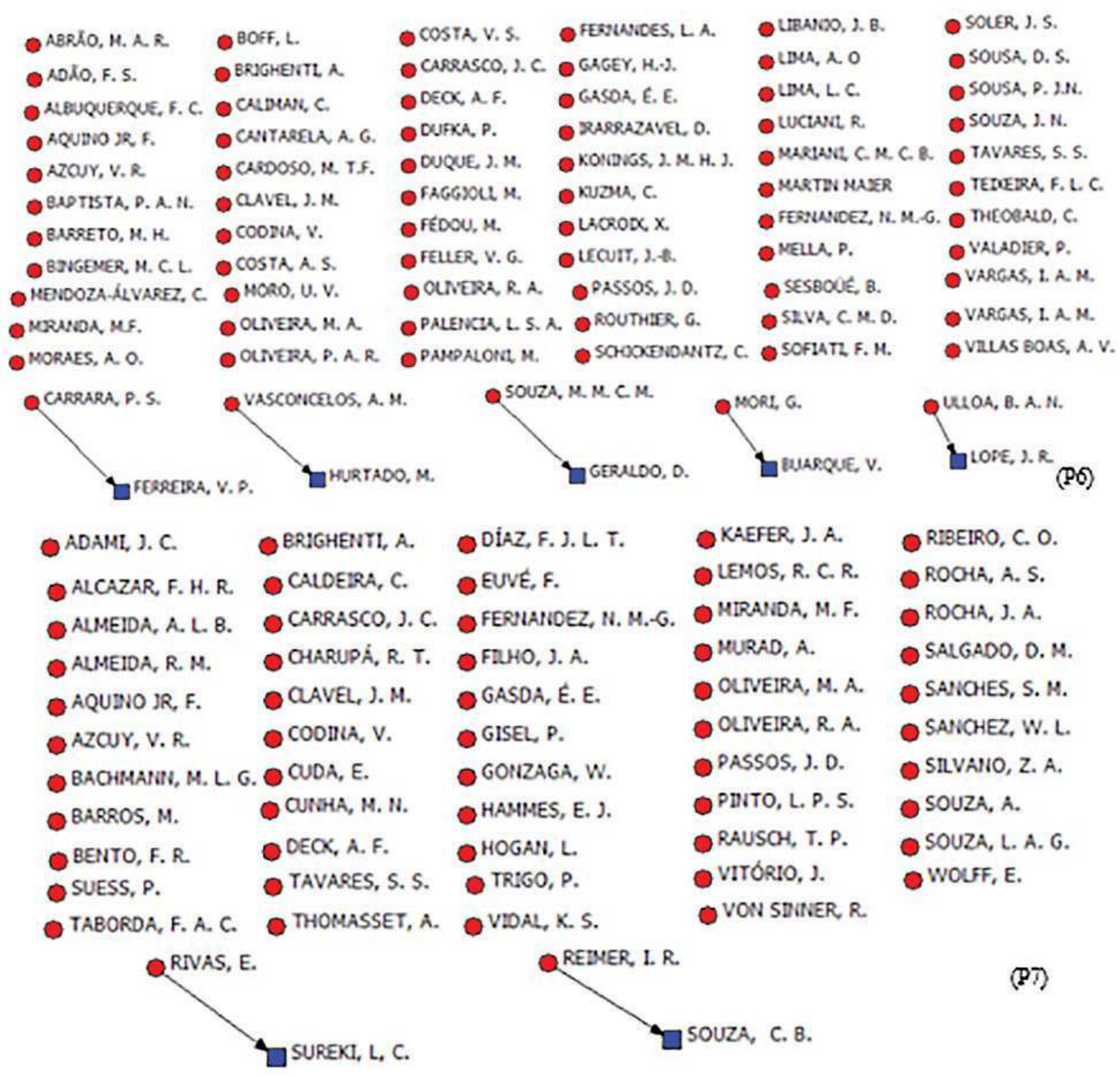

Fonte: Elaborado pelos autores, 2019. 
Ao se observar os dados quantitativos, verificou-se que de 1969 a 2019 (1 ${ }^{\text {a }}$ edição) a seguir são apresentados os atores pelo seu grau de centralidade, onde a centralidade de grau é identificada pela densidade nuclear (nó da rede) de cada ator, ou seja, quanto maior o nó que o autor apresenta, maior é a sua relevância na estruturada da rede. Levando em consideração que alguns períodos mapeados não apresentaram redes de relacionamento, conforme é representado nas figuras anteriores, aqui apresenta-se somente os mapeamentos que apresentaram redes, com suas centralidades, sendo eles: MA2 - 1980-1989 (P2); MA4 - 2000-2009 (P4); MA5 - 2010-2012 (P5); MA6 - 2013-2016 (P6); MA7 - 2017-2019 (1ª edição) (P7), conforme evidenciado nas figuras a seguir:

Figura 4 - Sociogramas Gerais das Redes por Grau de Centralidade MA2 1980-1989 (P2); MA4 - 2000-2009 (P4)

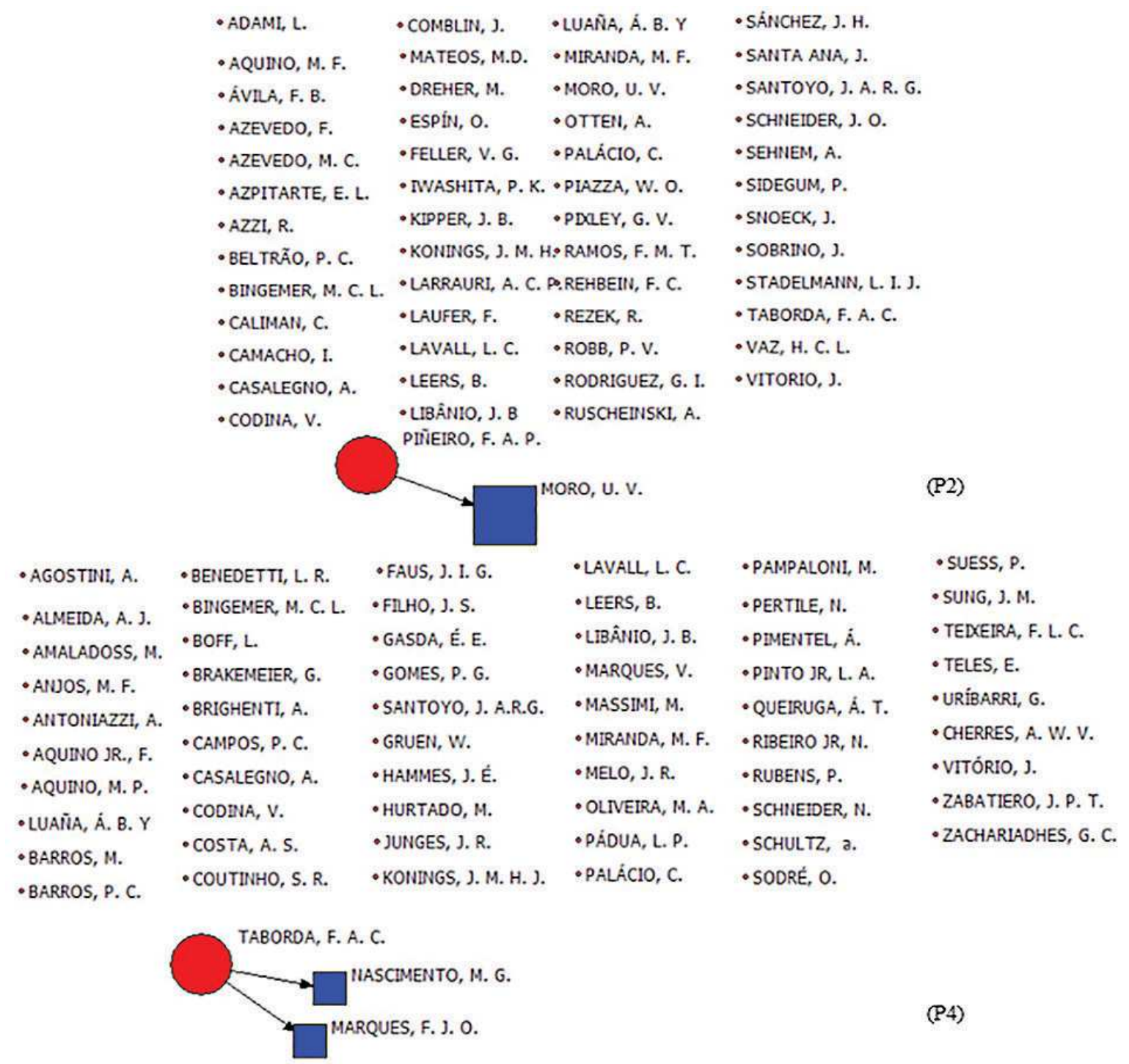

Fonte: Elaborado pelos autores, 2019. 
Figura 5 - Sociogramas Gerais das Redes por Grau de Centralidade MA5 2010-2012 (P5); MA6 - 2013-2016 (P6); MA7 - 2017-2019 (1ª edição) (P7)

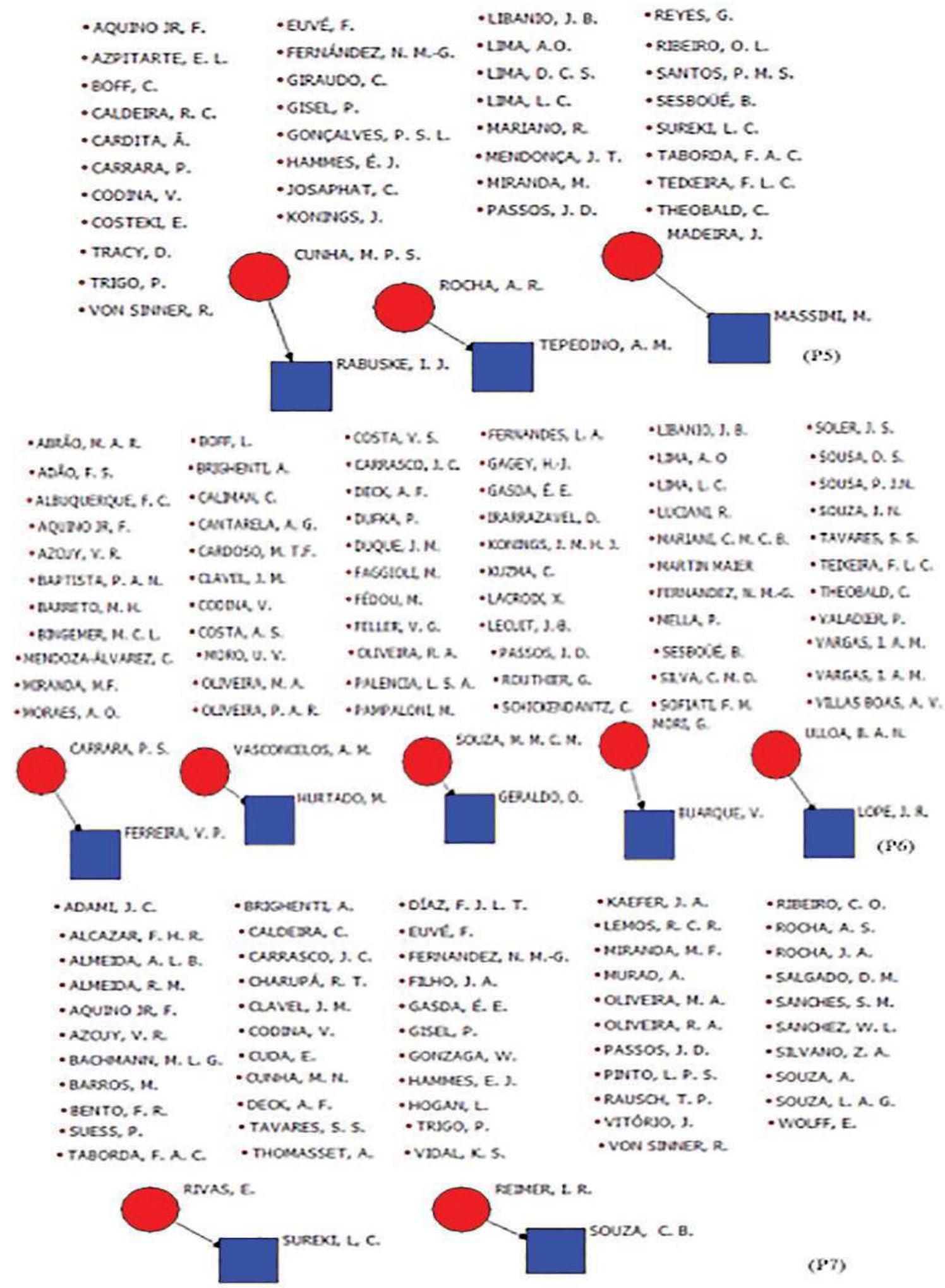

Fonte: Elaborado pelos autores, 2019. 
Ao se analisar os indicadores (figura acima), observa-se que a centralidade por autor indica o grau de inter-relação, o que sugere, neste contexto, que quanto maior a centralidade de um autor na rede, melhor se demonstra a sua importância na estrutura relacional entre os pesquisadores da área. Ao observar-se a figura acima percebe-se que poucos autores possuem rede de relacionamento com demais pesquisadores, o que demostra que poucos autores, que publicam na revista PT, possuem uma rede de relacionamentos, de acordo com os mapeamentos realizados. O grau de centralidade evidencia o número de laços que um autor possui com outros autores na rede, o que neste caso são poucos, o que representa poucas coautorias nos artigos publicados pela revista PT.

A tabela a seguir demonstra o grau de centralidade dos autores que assim apresentaram:

Tabela 2 - Centralidades por autor em relações gerais

\begin{tabular}{|c|c|c|c|c|c|c|c|c|c|}
\hline \multicolumn{2}{|c|}{$\begin{array}{c}\text { P2-MA2-Autores } \\
\text {-1980-1989 }\end{array}$} & \multicolumn{2}{|c|}{$\begin{array}{c}\text { P4-MA-4Autores } \\
-2000-2009\end{array}$} & \multicolumn{2}{c|}{$\begin{array}{c}\text { P5-MA5-Autores } \\
-2010-2012\end{array}$} & \multicolumn{2}{c|}{$\begin{array}{c}\text { P6-MA6-Autores } \\
-2013-2016\end{array}$} & \multicolumn{2}{c|}{$\begin{array}{c}\text { P7-MA7-Autores } \\
\mathbf{- 2 0 1 7 - 2 0 1 9}\left(\mathbf{1}^{\mathbf{a}} \text { ed) }\right.\end{array}$} \\
\hline Autores & $\begin{array}{c}\text { Cent } \\
\text { Grau }\end{array}$ & Autores & $\begin{array}{c}\text { Cent } \\
\text { Grau }\end{array}$ & Autores & $\begin{array}{c}\text { Cent } \\
\text { Grau }\end{array}$ & Autores & $\begin{array}{c}\text { Cent } \\
\text { Grau }\end{array}$ & Autores & $\begin{array}{c}\text { Cent } \\
\text { Grau }\end{array}$ \\
\hline PIÑEIRO, F. A. P. & 1000 & TABORDA, F. A. C. & 1000 & CUNHA, M. P. S. & 0.250 & CARRARA, P. S. & 0.200 & REIMER, I. R. & 0.500 \\
\hline & & & & FERREIRA, A. C. & 0.250 & MORI, G. & 0.200 & RIVAS, E. & 0.500 \\
\hline & & & & MADEIRA, J. & 0.250 & SOUZA, M. M. C. M. & 0.200 & & \\
\hline & & & & ROCHA, A. R. & 0.250 & ULLOA, B. A. N. & 0.200 & & \\
\hline
\end{tabular}

Fonte: Elaborado pelos autores, 2019.

\subsection{Perspectivas Temporais das Temáticas dos Dossiês da Revista Perspectiva Teológica}

Igualmente a análise dos autores que publicaram artigos científicos na revista PT, optou-se por dividir a análise dos dossiês no mesmo formato, correspondendo desta forma a estes autores foram divididos nos seguintes períodos: P1-MD1 - 1969-1979; P2-MD2 - 1980-1989; P3-MD3 - 1990-1999; P4-MD4 - 2000-2009; P5-MD5 - 2010-2012; P6-MD6 - 2013-2016; P7-MD7 2017-2019 (1a edição). Nesse sentido, as matrizes das temáticas dos dossiês foram estruturadas em uma matriz quadrada, de acordo com existência ou não de relações entre as principais temáticas da área. Tal separação procura evidenciar a evolução do campo de pesquisa numa relação temporal, procurando perceber a construção das relações nos períodos propostos na revista PT.

A revista mapeada apresentou, no período pesquisado, de 1969 a 2019 (1aㅡ edição), um total de 133 temáticas de dossiês publicados pela revista PT. A Tabela a seguir apresenta a distribuição dos dossiês nos períodos definidos pelos pesquisadores. 
Tabela 3 - Temáticas dos Dossiês Publicados nos Períodos

\begin{tabular}{|c|c|}
\hline Períodos & Total Dossiês \\
\hline P1 - MD1 - 1969-1979 & 20 \\
\hline P2 - MD2 - 1980-1989 & 24 \\
\hline P3 - MD3 - 1990-1999 & 29 \\
\hline P4-MD4-2000-2009 & 30 \\
\hline P5-MD5 - 2010-2012 & 9 \\
\hline P6-MD6-2013-2016 & 13 \\
\hline P7 - MD7 - 2017-2019 & 8 \\
\hline (1 ${ }^{\text {a }}$ edição) & $\mathbf{1 3 3}$ \\
\hline
\end{tabular}

Fonte: Elaborado pelos autores, 2019.

Do total das 133 temáticas de dossiês identificadas e publicadas pela revista PT ao longo do período pesquisado, cerca de $44 \%$ correspondem a temáticas de dossiês publicados nos períodos de P3 - MD3 - 1990-1999 e P4 - MD4 - 2000-2009, sendo $22 \%$ em cada um dos períodos pesquisados. Já o P2 - MD2 - 1980-1989 corresponde a 18\%. Para o P1 - MD1 - 1969-1979 tem-se 15\%. O P6 - MD6 - 2013-2016 elenca 10\%, sendo que o P5 - MD5 - 2010-2012 corresponde a 7\%, enquanto que o P7 - MD7 - 2017-2019 (1 $1^{\underline{a}}$ edição) apresenta-se com 6\%, lembrando que neste está contemplada apenas a $1^{a}$ edição do ano de 2019. O resultado pode ser observado no gráfico abaixo:

Gráfico 1 - \% Temáticas dos Dossiês por Períodos

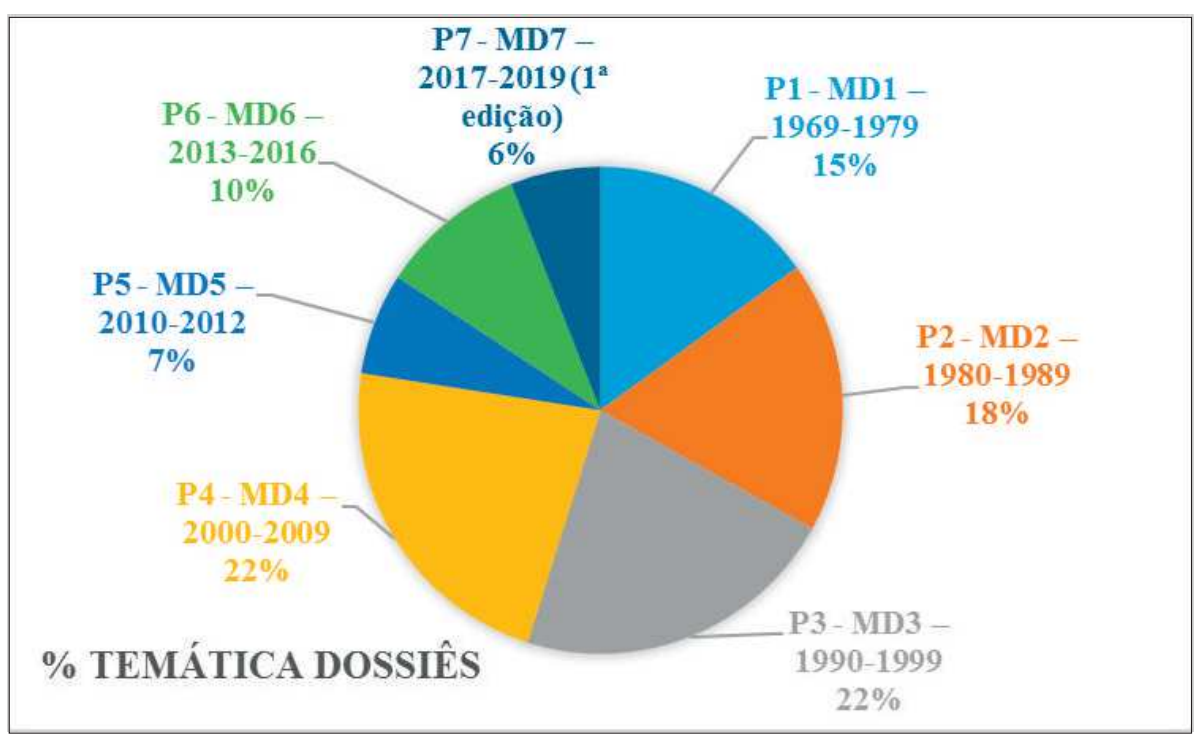

Fonte: Elaborado pelos autores, 2019. 


\subsection{Perfil dos Elos Relacionais das Temáticas dos Dossiês em Relação aos Autores}

Observando a perspectiva relacional entre os autores que publicaram na revista PT e as temáticas dos dossiês publicadas pela revista, no período pesquisado (1969-2019 [1a edição]), é apresentado o mapeamento dos elos relacionais entre os autores e as temáticas. Nesse sentido, os dossiês foram estruturados em matriz quadrada de acordo com existência ou não de relações entre os autores e as temáticas.

Conforme se observa nas Figuras a seguir, no período P1-MD1 - 19691979 foram identificadas 20 temáticas de dossiês. No P2-MD2 - 1980-1989 foram identificadas 24 temáticas de dossiês. No P3-MD3 - 1990-1999 foram identificadas 29 temáticas de dossiês. No P4-MD4 - 2000-2009 foram identificadas 30 temáticas de dossiês. No P5-MD5 - 2010-2012 foram identificadas 9 temáticas de dossiês, no P6-MD6 - 2013-2016 foram identificadas 13 temáticas de dossiês e no P7-MD7 - 2017-2019 (1ª edição) foram identificadas 8 temáticas de dossiês até a $1^{\underline{a}}$ edição. Observe a seguir o sociograma geral de cada um dos períodos propostos.

Figura 6 - Sociograma Geral da Rede P1-MD1 - 1969-1979

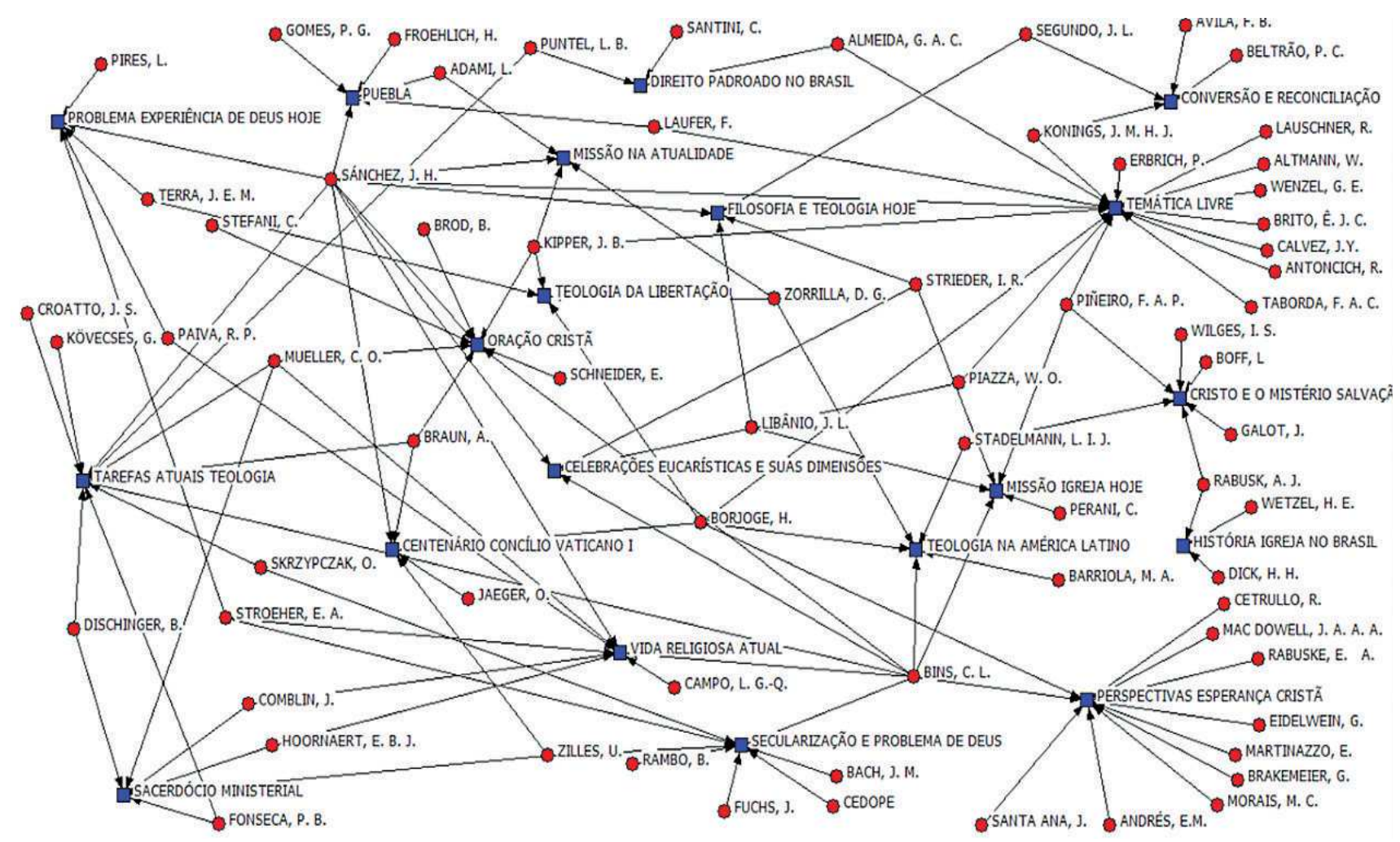

Fonte: Elaborado pelos autores, 2019. 
Figura 7 - Sociograma Geral da Rede P2-MD2 - 1980-1989

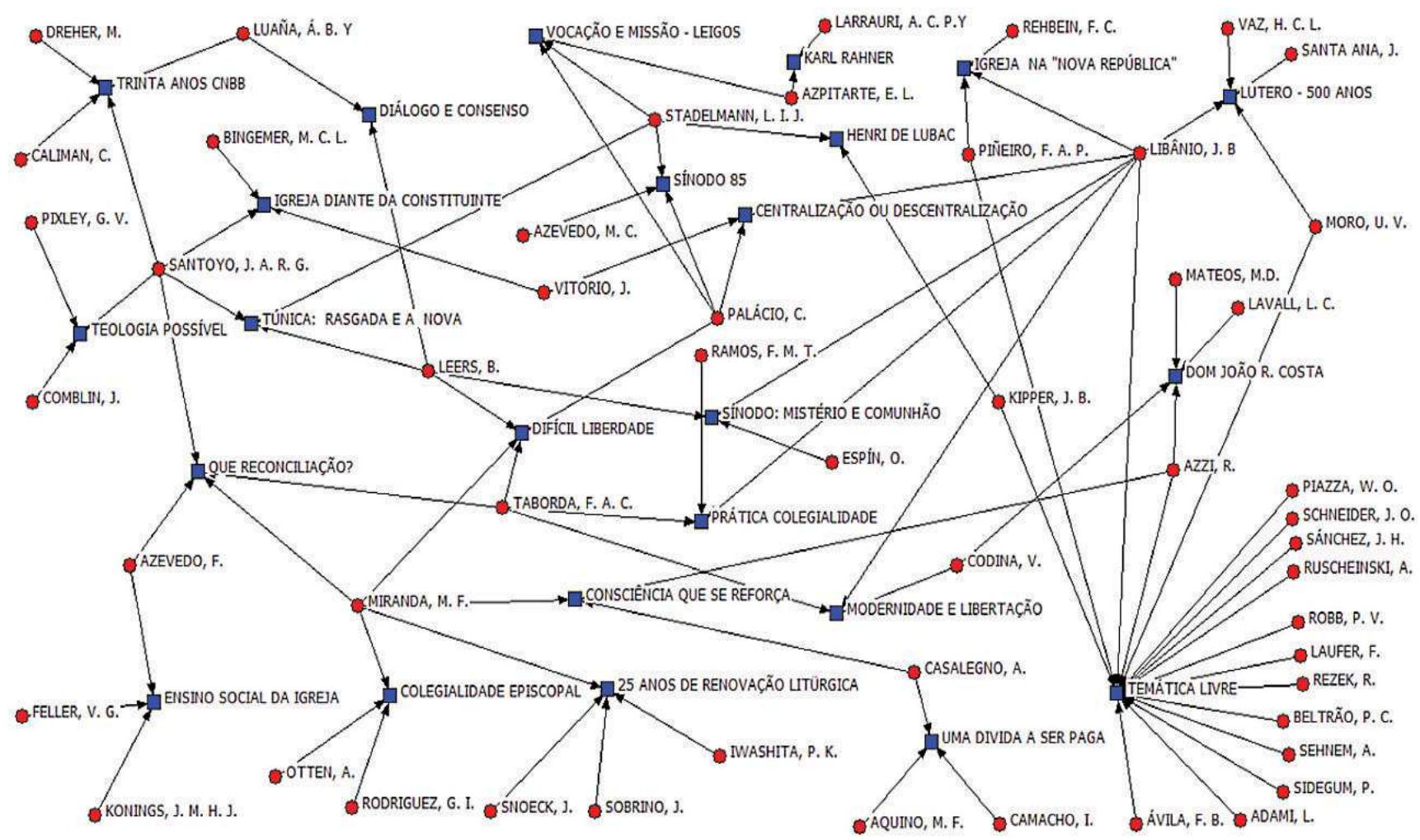

Fonte: Elaborado pelos autores, 2019.

Figura 8 - Sociograma Geral da Rede P3-MD3 - 1990-1999

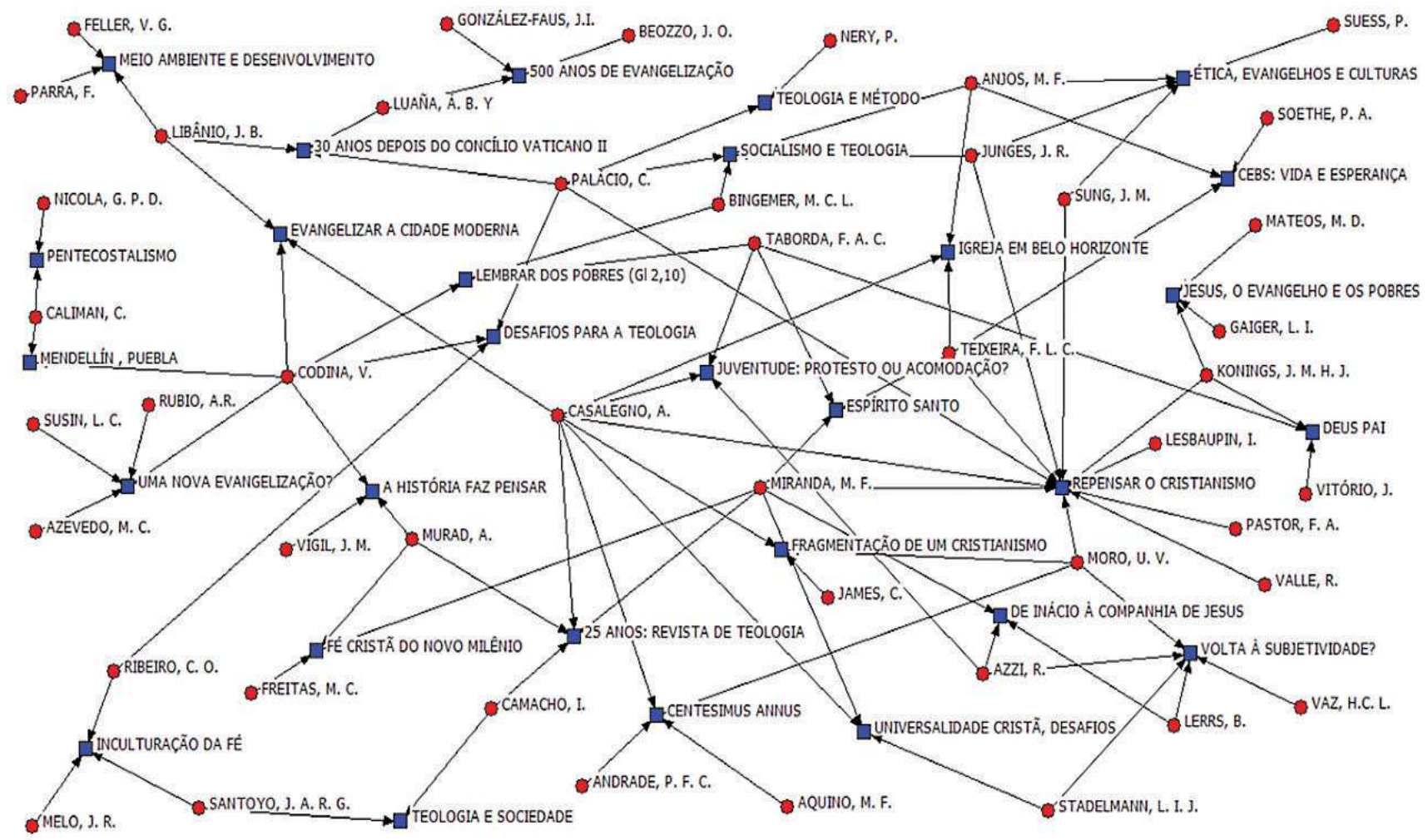

Fonte: Elaborado pelos autores, 2019. 
Figura 9 - Sociograma Geral da Rede P4-MD4 - 2000-2009

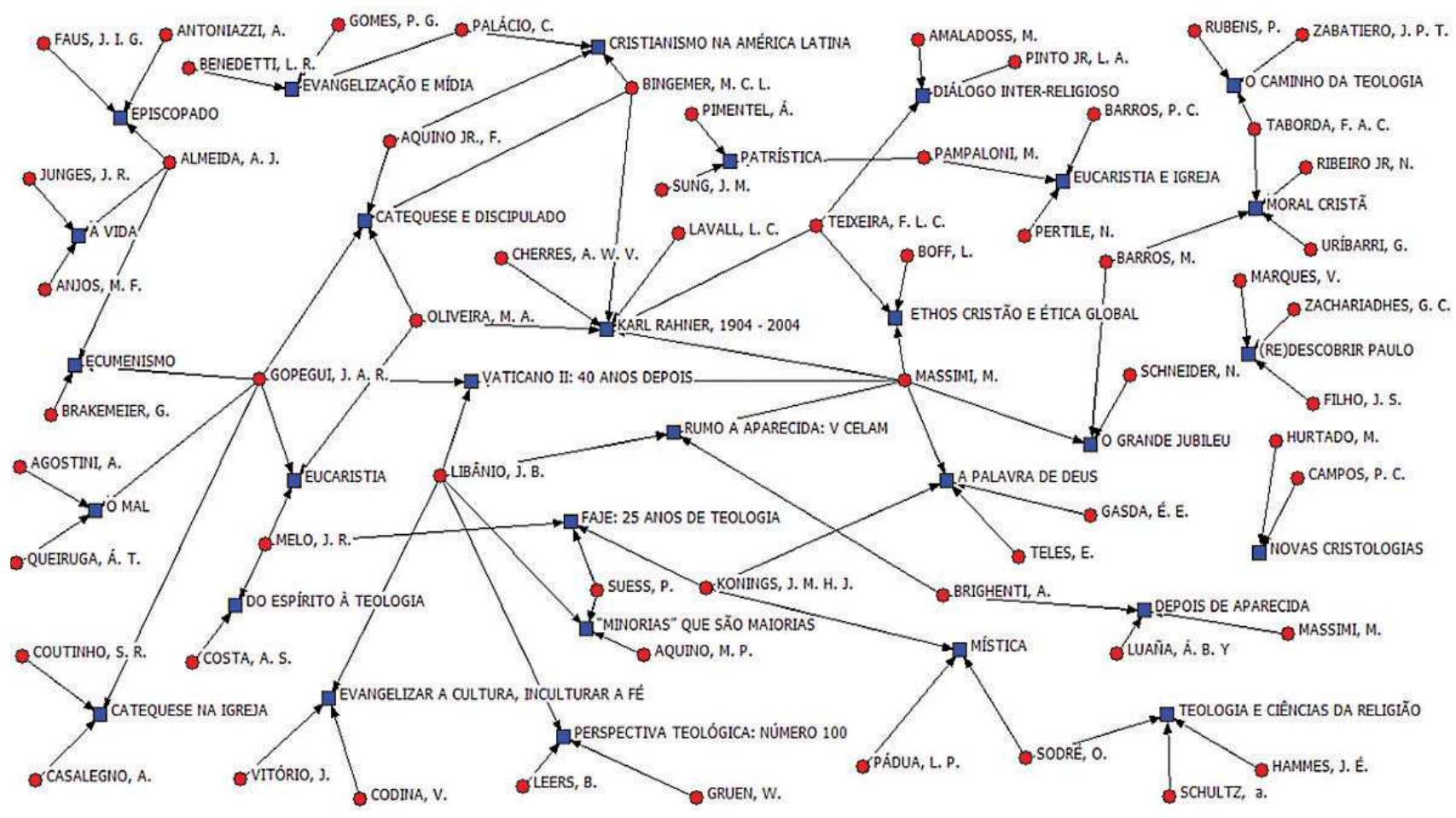

Fonte: Elaborado pelos autores, 2019.

Figura 10 - Sociograma Geral da Rede P5-MD5 - 2010-2012

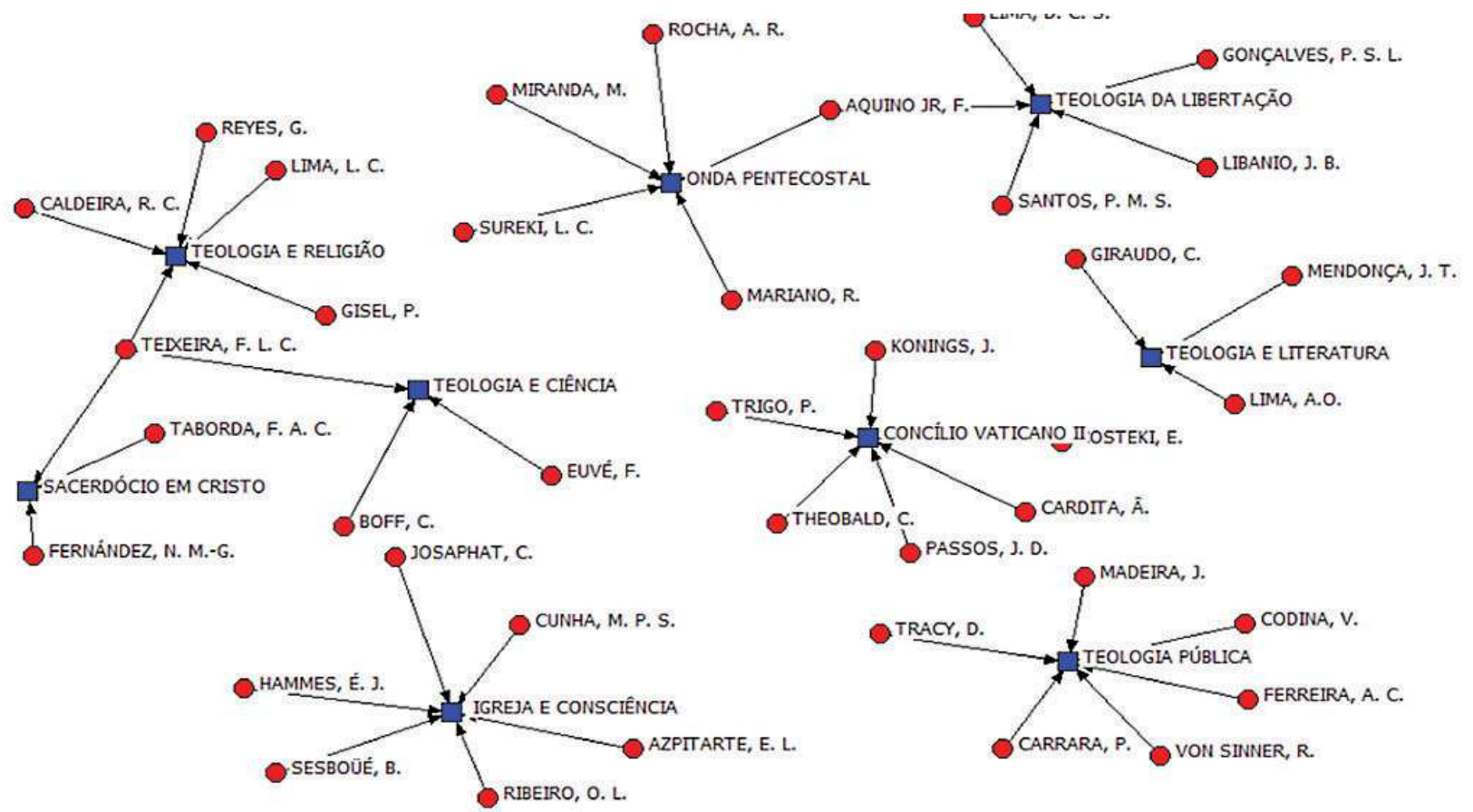

Fonte: Elaborado pelos autores, 2019. 
Figura 11 - Sociograma Geral da Rede P6-MD6 - 2013-2016

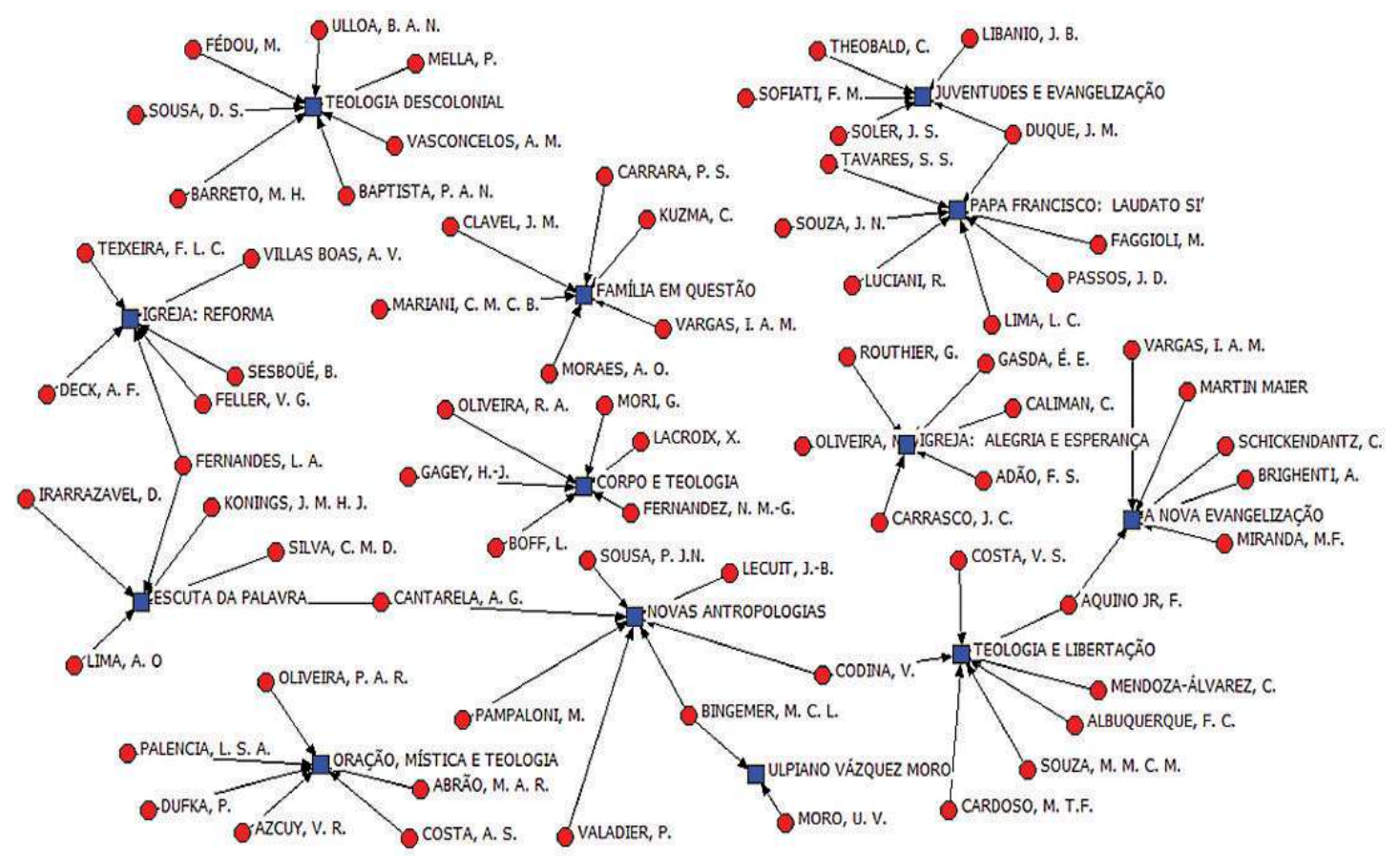

Fonte: Elaborado pelos autores, 2019.

Figura 12 - Sociograma Geral da Rede P7-MD7 - 2017-2019 (1ª edição)

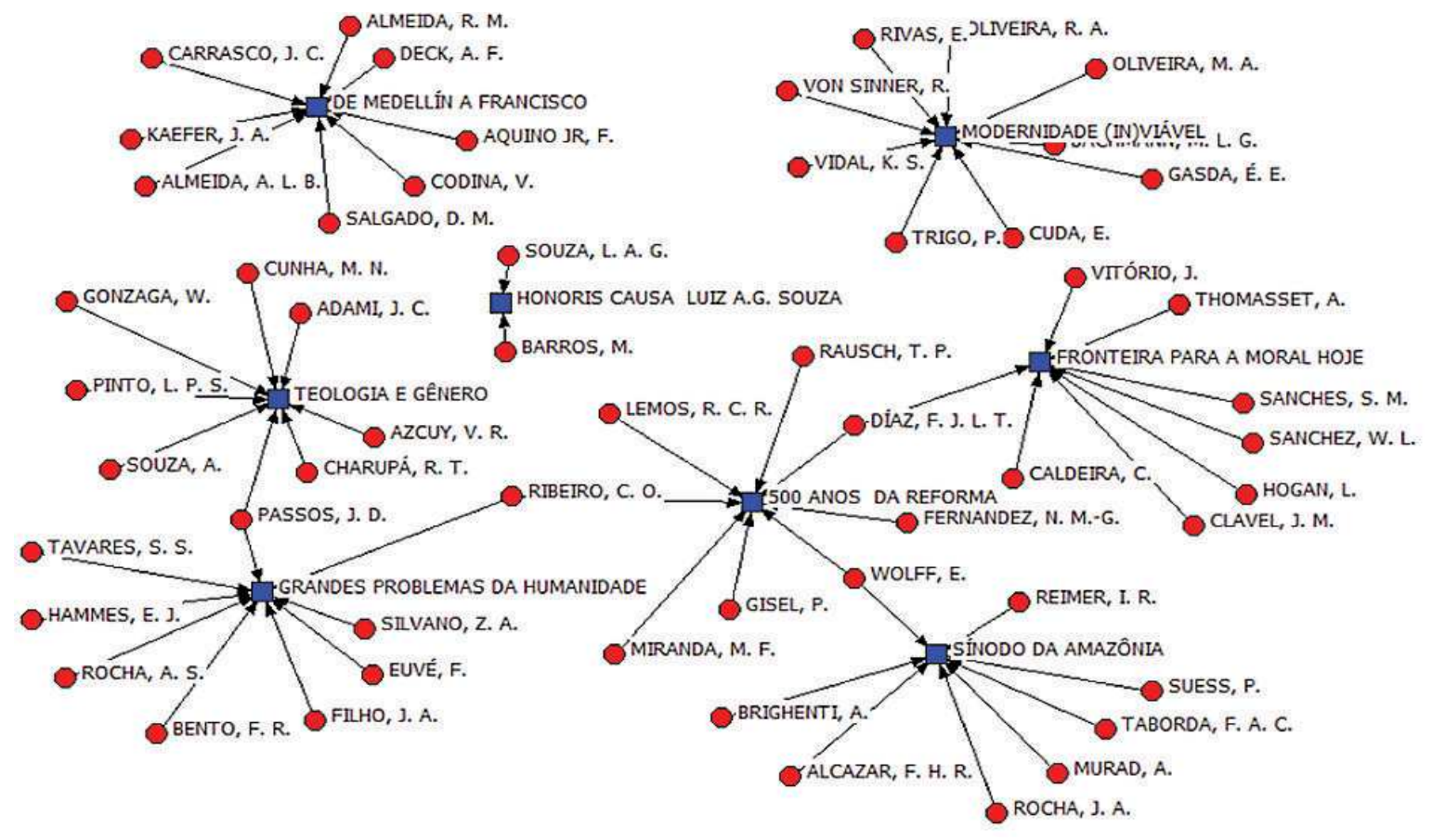

Fonte: Elaborado pelos autores, 2019.

As figuras a seguir demonstram os sociogramas da centralidade das temáticas dos dossiês e os autores que publicaram na revista PT em cada período estudado. É importante ressaltar que o grau de centralidade revela 
o quanto uma temática de dossiê está ligada aos autores que publicaram na revista em cada período mapeado.

Figura 13 - Sociograma Geral por Centralidade da Rede P1-MD1 - 1969-1979

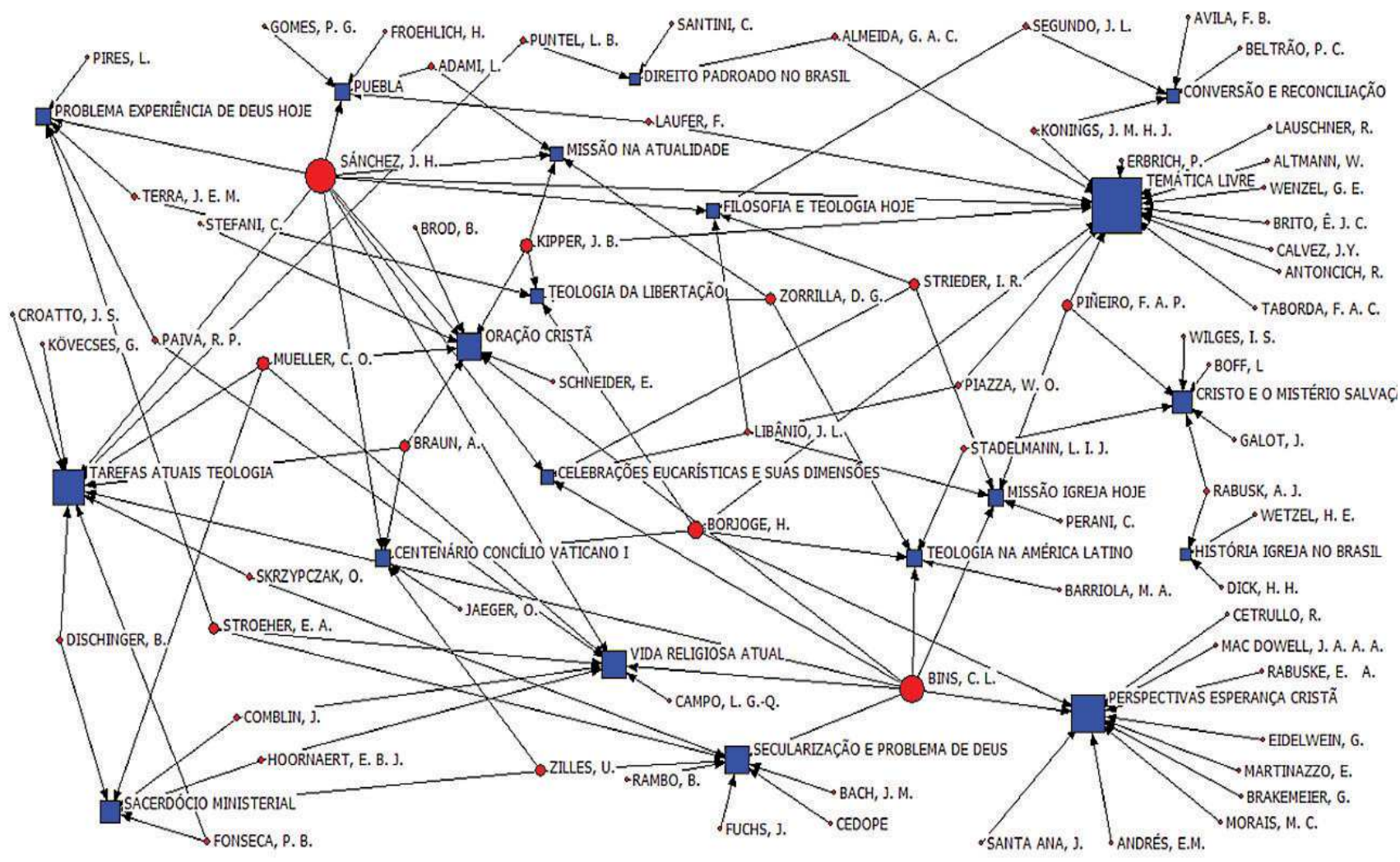

Fonte: Elaborado pelos autores, 2019.

Figura 14 - Sociograma Geral por Centralidade da Rede P2-MD2 - 1980-1989

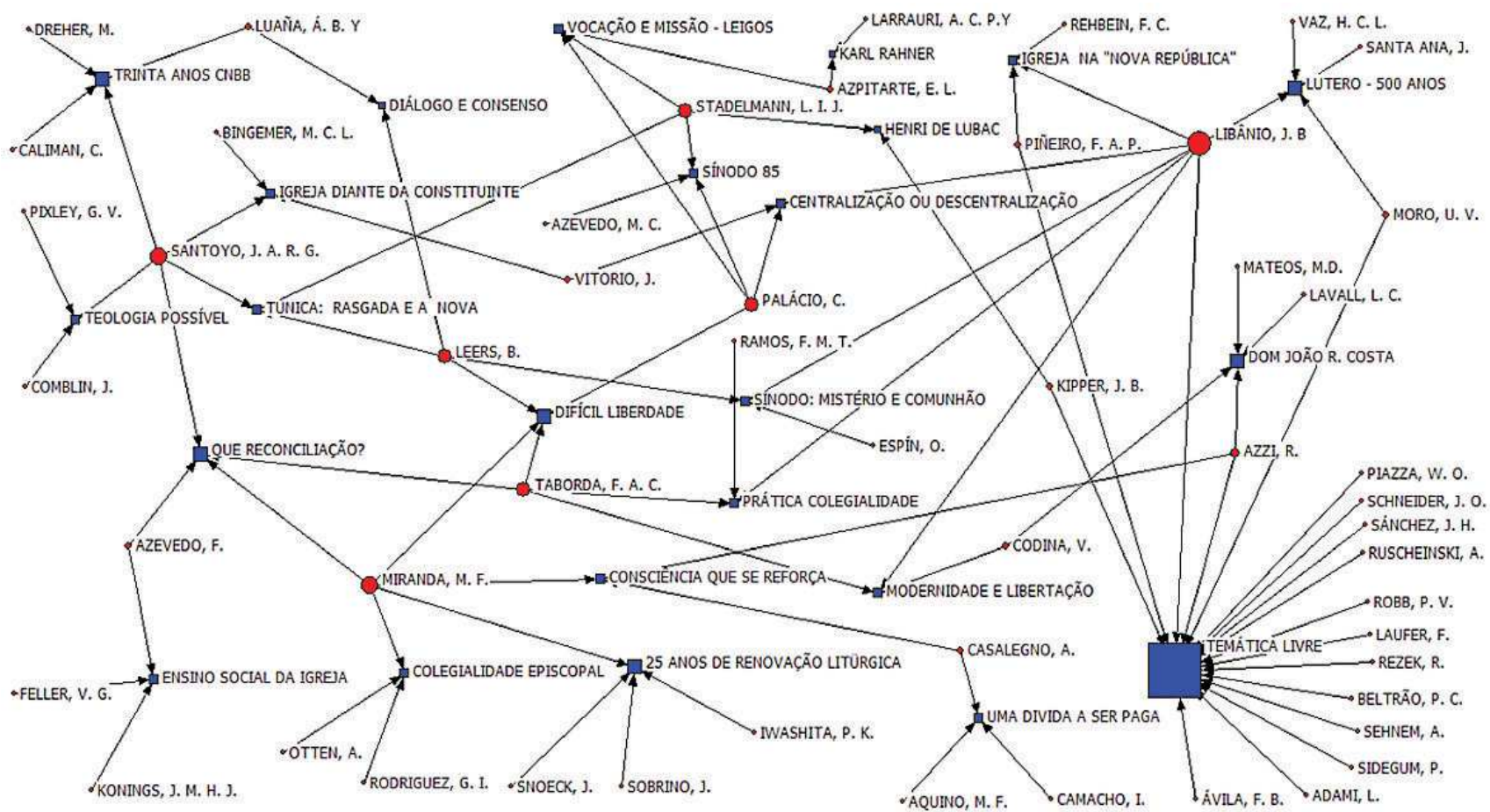

Fonte: Elaborado pelos autores, 2019. 
Figura 15 - Sociograma Geral por Centralidade da Rede P3-MD3 - 1990-1999

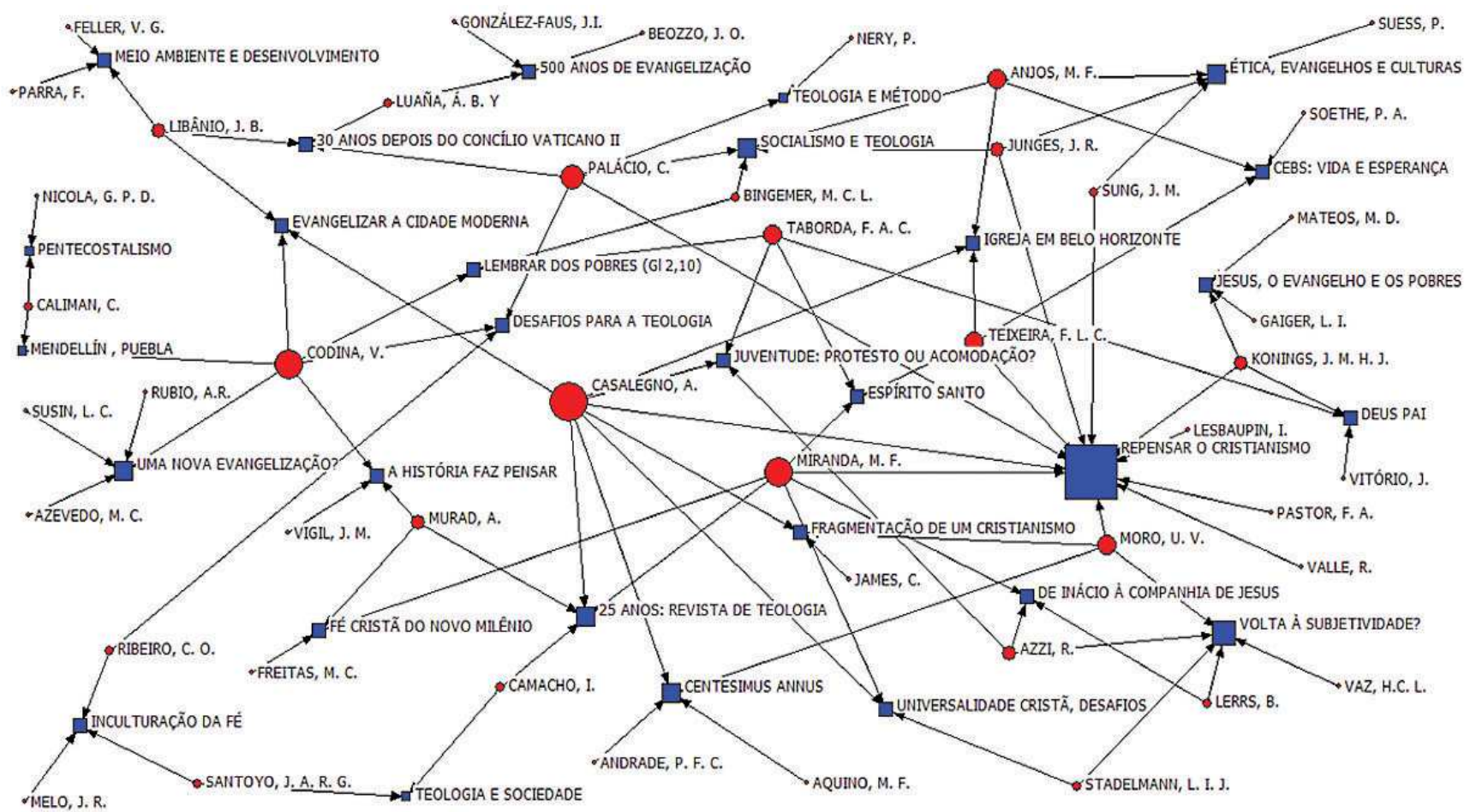

Fonte: Elaborado pelos autores, 2019.

Figura 16 - Sociograma Geral por Centralidade da Rede P4-MD4 - 2000-2009

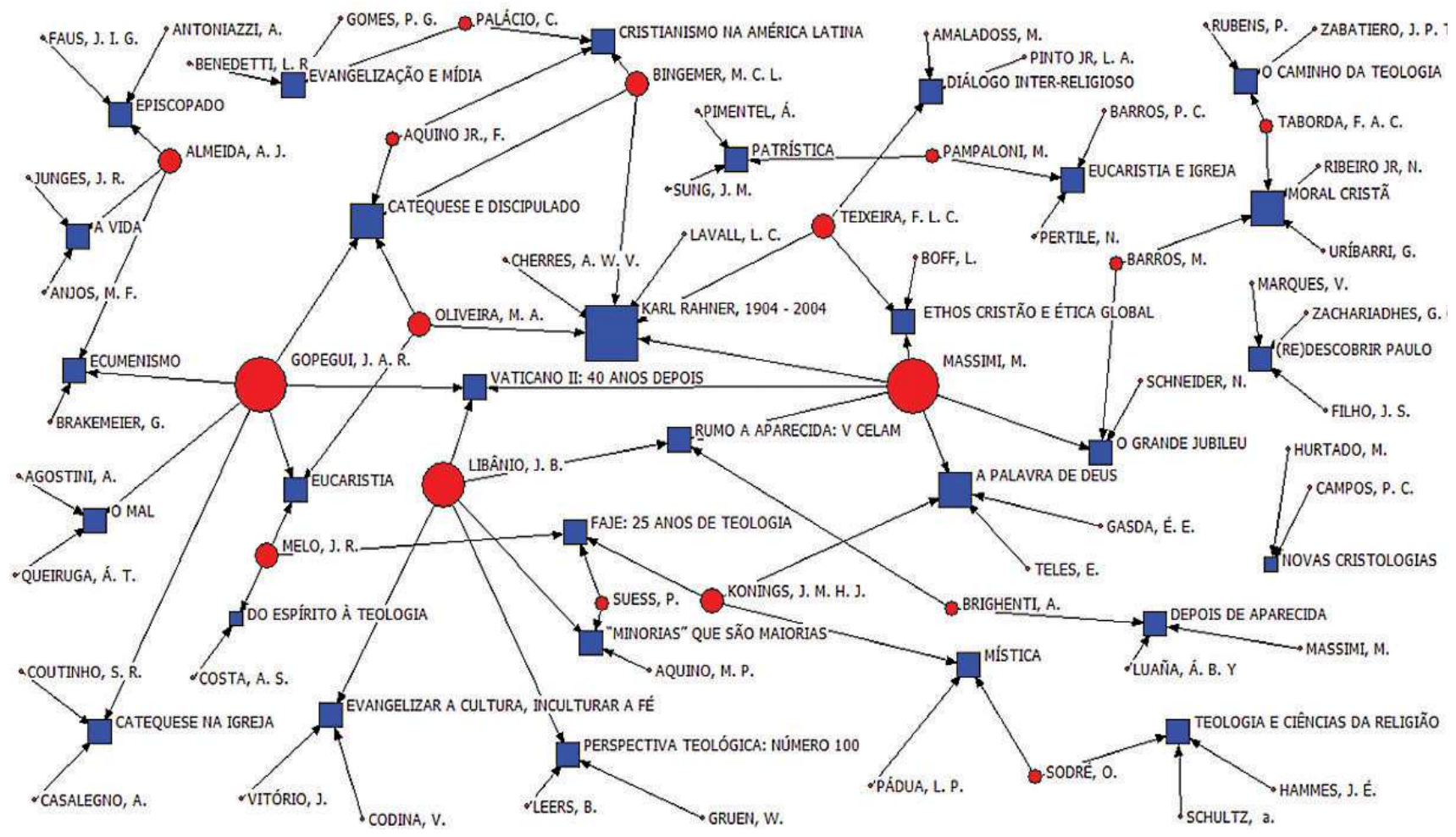

Fonte: Elaborado pelos autores, 2019. 
Figura 17 - Sociograma Geral por Centralidade da Rede P5-MD5 - 2010-2012

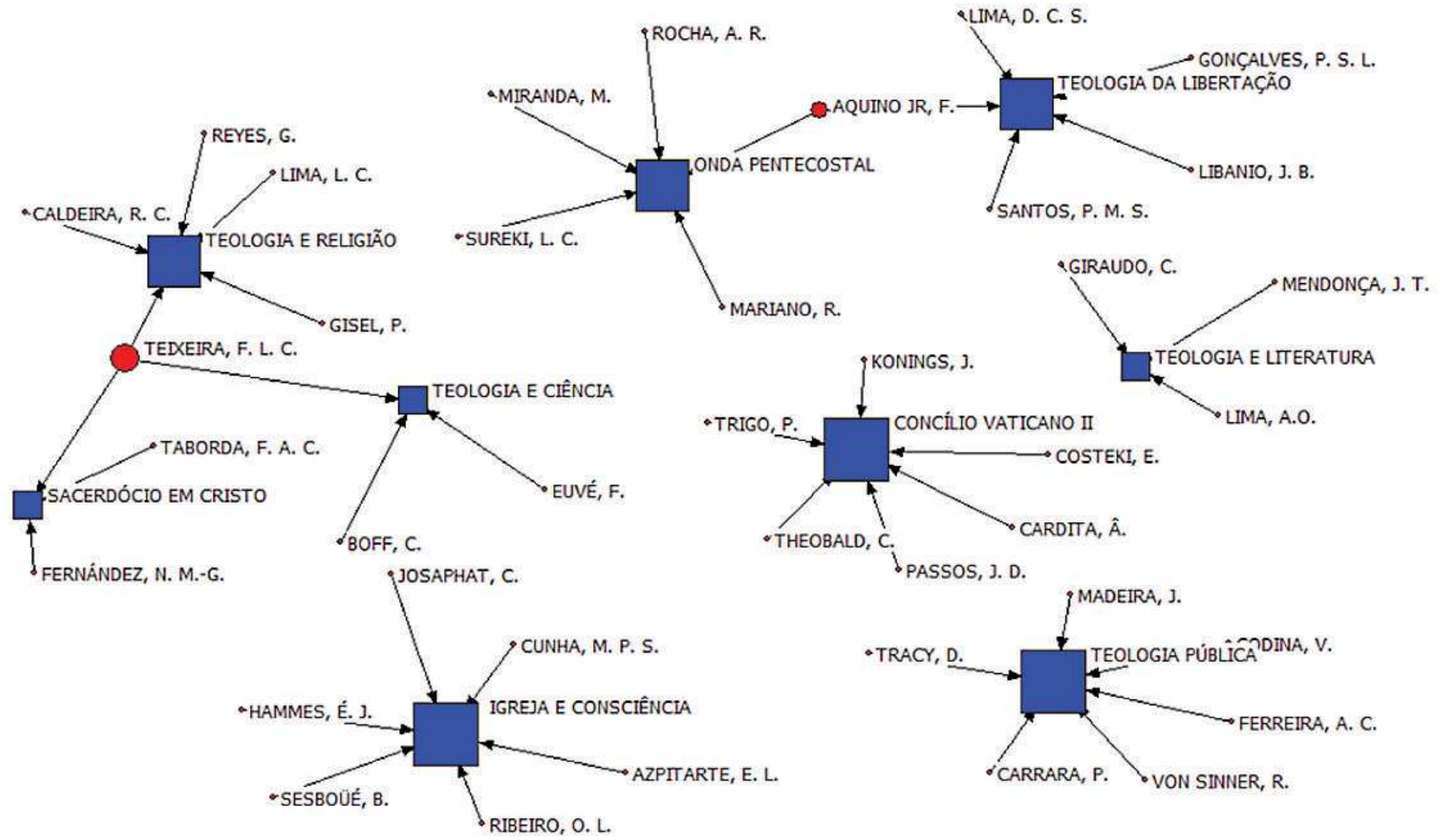

Fonte: Elaborado pelos autores, 2019.

Figura 18 - Sociograma Geral por Centralidade da Rede P6-MD6 - 2013-2016

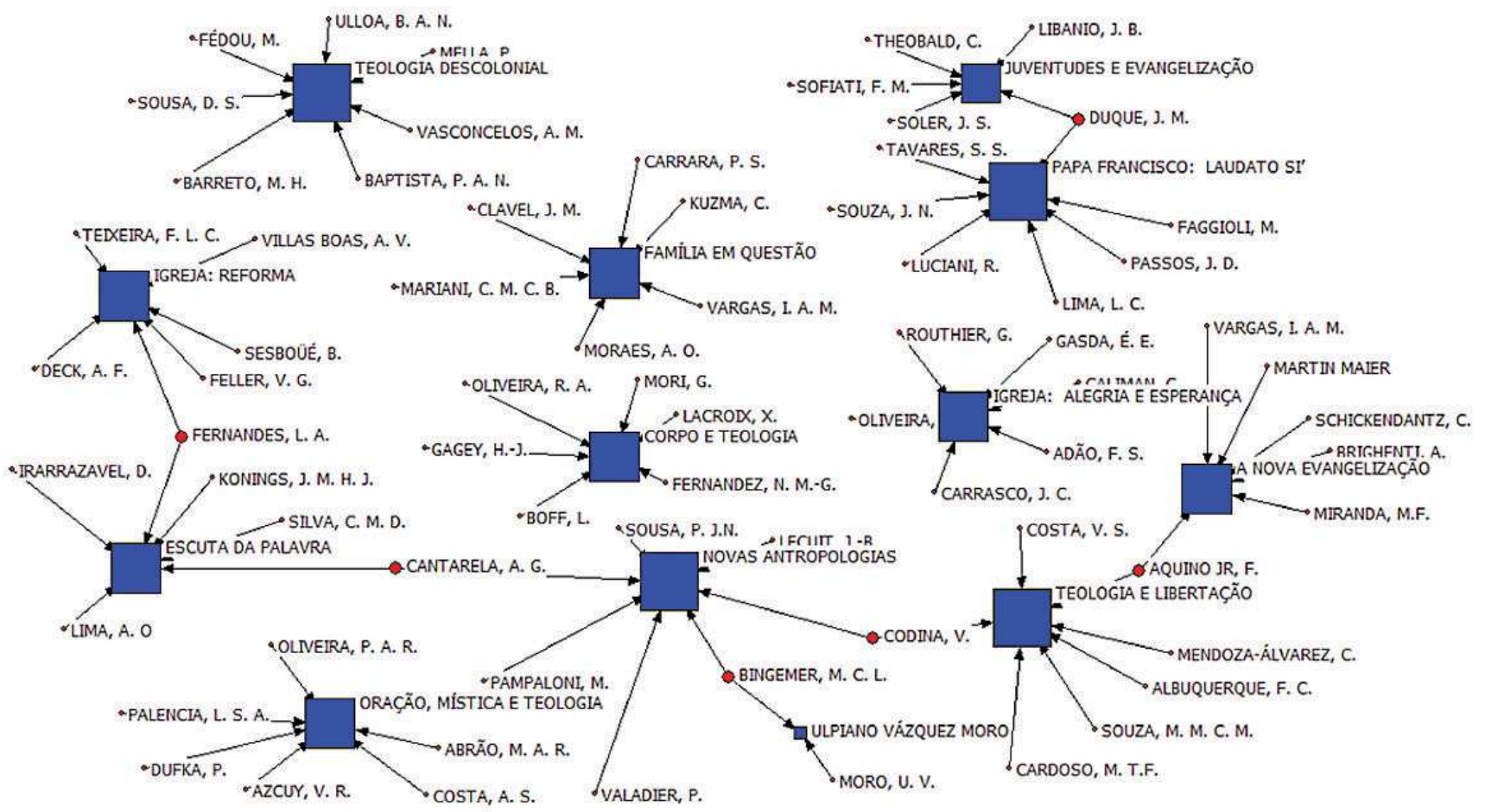

Fonte: Elaborado pelos autores, 2019. 
Figura 19 - Sociograma Geral por Centralidade da Rede P7-MD7 - 2017-2019 (1ª edição)
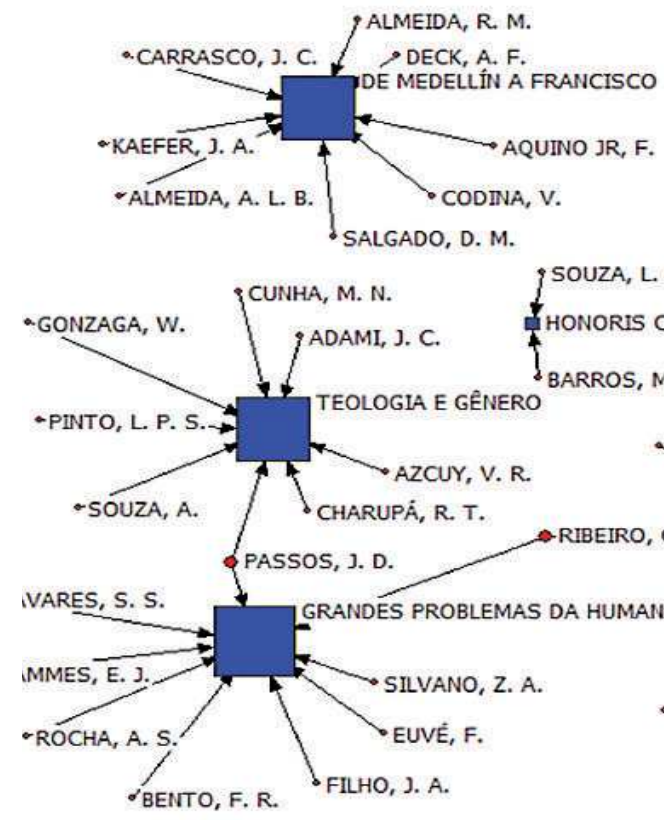

SOUZA, L. A. G.
HONORIS CAUSA LUIZ A.G. SOUZA

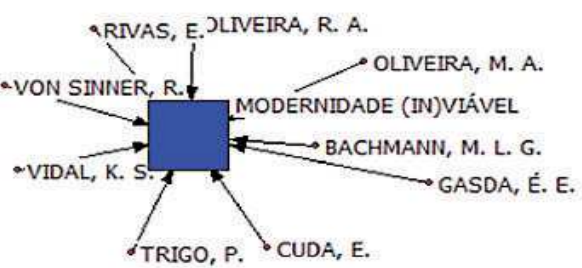

BARROS, M.

TRIGO, P. CUDA, E.

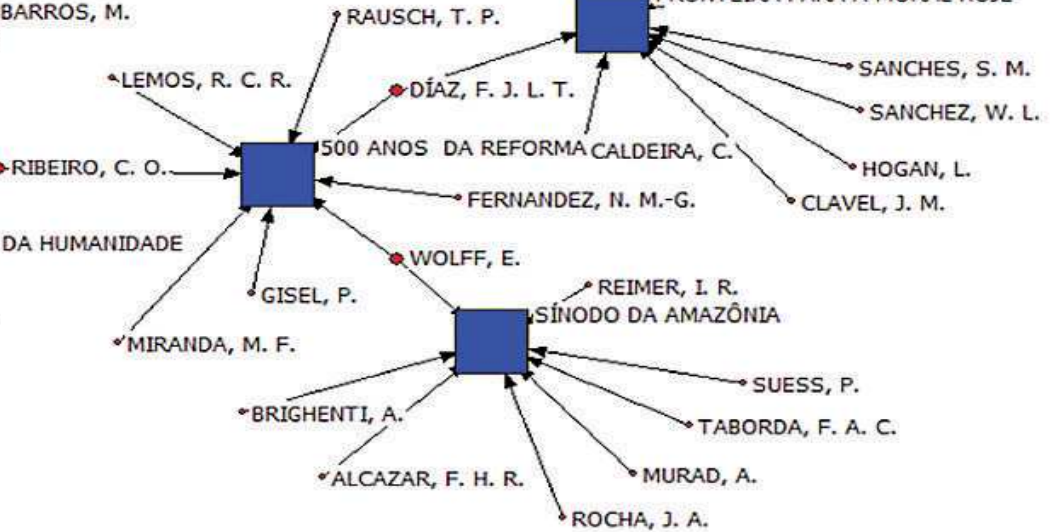

Fonte: Elaborado pelos autores, 2019.

É possível identificar na Tabela 4, a seguir, o nível de centralidade de grau, ou seja, o grau de inter-relação de cada autor que publicou na revista e as temáticas dos dossiês da revista PT. Para apresentação dos dados dos períodos, os mesmos foram divididos em grupos de tabelas.

Tabela 4 - Centralidade por Temática de Dossiê da Revista Perspectiva Teológica: P1-MD1 - 1969-1979 e P2-MD2 - 1980-1989

\begin{tabular}{|c|c|c|c|}
\hline \multicolumn{2}{|l|}{ P1-MD1 - 1969-1979 } & \multicolumn{2}{|l|}{ P2-MD2 - 1980-1989 } \\
\hline Temáticas Dossiês & $\begin{array}{l}\text { Cent } \\
\text { Grau }\end{array}$ & Temáticas Dossiês & $\begin{array}{l}\text { Cent } \\
\text { Grau }\end{array}$ \\
\hline DIREITO PADROADO NO BRASIL & 0.043 & HENRI DE LUBAC & 0.038 \\
\hline HISTÓRIA IGREJA NO BRASIL & 0.043 & DIÁLOGO E CONSENSO & 0.038 \\
\hline CONVERSÃO E RECONCILIAÇÃO & 0.058 & KARL RAHNER & 0.038 \\
\hline CELEBRAÇÕES EUCARÍSTICAS E SUAS DIMENSÕES & 0.058 & TEOLOGIA POSSÍVEL & 0.058 \\
\hline FILOSOFIA E TEOLOGIA HOJE & 0.058 & PRÁTICA COLEGIALIDADE & 0.058 \\
\hline MISSÃO NA ATUALIDADE & 0.058 & IGREJA NA "NOVA REPÚBLICA" & 0.058 \\
\hline TEOLOGIA DA LIBERTAÇÃO & 0.058 & SÍNODO 85 & 0.058 \\
\hline CENTENÁRIO CONCÍLIO VATICANO I & 0.072 & SÍNODO: MISTÉRIO E COMUNHÃO & 0.058 \\
\hline PROBLEMA EXPERIÊNCIA DE DEUS HOJE & 0.072 & CONSCIÊNCIA QUE SE REFORÇA & 0.058 \\
\hline MISSÃO IGREJA HOJE & 0.072 & IGREJA DIANTE DA CONSTITUINTE & 0.058 \\
\hline FAZER TEOLOGIA NA AMÉRICA LATINO & 0.072 & VOCAÇÃO E MISSÃO - LEIGOS & 0.058 \\
\hline PUEBLA & 0.072 & MODERNIDADE E LIBERTAÇÃO & 0.058 \\
\hline SACERDÓCIO MINISTERIAL & 0.087 & UMA DIVIDA A SER PAGA & 0.058 \\
\hline CRISTO E O MISTÉRIO SALVAÇÃO & 0.087 & ENSINO SOCIAL DA IGREJA & 0.058 \\
\hline VIDA RELIGIOSA ATUAL & 0.116 & TÚNICA: RASGADA E A NOVA & 0.058 \\
\hline SECULARIZAÇÃO E PROBLEMA DE DEUS & 0.116 & COLEGIALIDADE EPISCOPAL & 0.058 \\
\hline ORAÇÃO CRISTÃ & 0.116 & $\begin{array}{l}\text { CENTRALIZAÇÃO OU } \\
\text { DESCENTRALIZAÇÃO }\end{array}$ & 0.058 \\
\hline TAREFAS ATUAIS TEOLOGIA & 0.145 & DIFÍCIL LIBERDADE & 0.077 \\
\hline PERSPECTIVAS ESPERANÇA CRISTÃ & 0.159 & TRINTA ANOS CNBB & 0.077 \\
\hline TEMÁTICA LIVRE & 0.232 & QUE RECONCILIAÇÃO? & 0.077 \\
\hline & & LUTERO - 500 ANOS & 0.077 \\
\hline & & DOM JOÃO R. COSTA & 0.077 \\
\hline & & 25 ANOS DE RENOVAÇÃO LITÜRGICA & 0.077 \\
\hline & & TEMÁTICA LIVRE & 0.327 \\
\hline
\end{tabular}

Legenda: Fonte: Elaborado pelos autores, 2019. 
Na tabela 4 é possível observar que em cada período pesquisado da revista PT, as temáticas de dossiês que aparecem com maior centralidade de grau em cada período, destacam-se as com maiores centralidades de grau:

a MD1 - 1969-1979 destacam-se: Temática Livre (0.232); Perspectivas da Esperança Cristã (0.159); Tarefas Atuais Teologia (0.145); Oração Cristã (0.116); Secularização e Problema de Deus (0.116); Vida Religiosa Atual (0.116); Cristo e o Mistério da Salvação (0.087) e Sacerdócio Ministerial (0.087);

b MD2 - 1980-1989 destacam-se: Temática Livre (0.327); 25 anos de Renovação Litúrgica (0.077); Dom João R. Costa (0.077); Lutero - 500 anos (0.077); Que Reconciliação? (0.077); Trinta anos CNBB (0.077); Difícil Liberdade (0.077);

Tabela 5 - Centralidade por Temática de Dossiê da Revista Perspectiva Teológica:

P3-MD3 - 1990-1999 e P4-MD4 - 2000-2009

\begin{tabular}{|c|c|c|c|}
\hline $\begin{array}{l}\text { P3-MD3 - 1990-1999 } \\
\text { Temáticas Dossiês }\end{array}$ & $\begin{array}{l}\text { Cent } \\
\text { Grau }\end{array}$ & $\begin{array}{l}\text { P4-MD4 - 2000-2009 } \\
\text { Temáticas Dossiês }\end{array}$ & $\begin{array}{l}\text { Cent } \\
\text { Grau }\end{array}$ \\
\hline PENTECOSTALISMO & 0.043 & DO ESPÍRITO À TEOLOGIA & 0.033 \\
\hline TEOLOGIA E SOCIEDADE & 0.043 & NOVAS CRISTOLOGIAS & 0.033 \\
\hline TEOLOGIA E MÉTODO & 0.043 & O GRANDE JUBILEU & 0.050 \\
\hline MENDELLÍN, PUEBLA & 0.043 & EUCARISTIA & 0.050 \\
\hline LEMBRAR DOS POBRES $(\mathrm{Gl} 2,10)$ & 0.065 & EPISCOPADO & 0.050 \\
\hline DE INÁCIO À COMPANHIA DE JESUS & 0.065 & A VIDA & 0.050 \\
\hline JUVENTUDE: PROTESTO OU ACOMODAÇÃO? & 0.065 & ECUMENISMO & 0.050 \\
\hline MEIO AMBIENTE E DESENVOLVIMENTO & 0.065 & $\mathrm{O} \mathrm{MAL}$ & 0.050 \\
\hline 500 ANOS DE EVANGELIZAÇÃO & 0.065 & “MINORIAS” QUE SÃO MAIORIAS & 0.050 \\
\hline JESUS, O EVANGELHO E OS POBRES & 0.065 & DIÁLOGO INTER-RELIGIOSO & 0.050 \\
\hline UNIVERSALIDADE CRISTÃ, DESAFIOS & 0.065 & EVANGELIZAÇÃO E MÍDIA & 0.050 \\
\hline A HISTÓRIA FAZ PENSAR & 0.065 & MÍSTICA & 0.050 \\
\hline DESAFIOS PARA A TEOLOGIA & 0.065 & PATRÍSTICA & 0.050 \\
\hline 30 ANOS DEPOIS DO CONCÍLIO VATICANO II & 0.065 & CRISTIANISMO NA AMÉRICA LATINA & 0.050 \\
\hline EVANGELIZAR A CIDADE MODERNA & 0.065 & PERSPECTIVA TEOLÓGICA: NÚMERO 100 & 0.050 \\
\hline FRAGMENTAÇÃO DE UM CRISTIANISMO & 0.065 & VATICANO II: 40 ANOS DEPOIS & 0.050 \\
\hline FÉ CRISTÃ DO NOVO MILÊNIO & 0.065 & EUCARISTIA E IGREJA & 0.050 \\
\hline CEBS: VIDA E ESPERANÇA & 0.065 & CATEQUESE NA IGREJA & 0.050 \\
\hline INCULTURAÇÃO DA FÉ & 0.065 & O CAMINHO DA TEOLOGIA & 0.050 \\
\hline IGREJA EM BELO HORIZONTE & 0.065 & RUMO A APARECIDA: V CELAM & 0.050 \\
\hline ESPÍRITO SANTO & 0.065 & FAJE: 25 ANOS DE TEOLOGIA & 0.050 \\
\hline DEUS PAI & 0.065 & TEOLOGIA E CIÊNCIAS DA RELIGIÃO & 0.050 \\
\hline UMA NOVA EVANGELIZAÇÃO? & 0.087 & DEPOIS DE APARECIDA & 0.050 \\
\hline SOCIALISMO E TEOLOGIA & 0.087 & $\begin{array}{l}\text { EVANGELIZAR A CULTURA, INCULTURAR } \\
\text { A FÉ }\end{array}$ & 0.050 \\
\hline CENTESIMUS ANNUS & 0.087 & ETHOS CRISTÃO E ÉTICA GLOBAL & 0.050 \\
\hline 25 ANOS: REVISTA DE TEOLOGIA & 0.087 & (RE)DESCOBRIR PAULO & 0.050 \\
\hline ÉTICA, EVANGELHOS E CULTURAS & 0.087 & MORAL CRISTÃ & 0.067 \\
\hline VOLTA À SUBJETIVIDADE? & 0.109 & A PALAVRA DE DEUS & 0.067 \\
\hline \multirow[t]{2}{*}{ REPENSAR O CRISTIANISMO } & 0.239 & CATEQUESE E DISCIPULADO & 0.067 \\
\hline & & KARL RAHNER, 1904 - 2004 & 0.100 \\
\hline
\end{tabular}

Legenda: Fonte: Elaborado pelos autores, 2019.

Na tabela 5 é possível observar que em cada período pesquisado da revista PT, as temáticas de dossiês que aparecem com maior centralidade de grau, em cada período destacam-se as com maiores centralidades de grau: 
a MD3 - 1990-1999 destacam-se: Repensar o Cristianismo (0.239); Volta à Subjetividade? (0.109); Ética, Evangelhos e Culturas (0.087); 25 Anos: Revista de Teologia (0.087); Centesimus Annus (0.087); Socialismo e Teologia (0.087); Uma Nova Evangelização? (0.087);

b MD4 - 2000-2009 destacam-se: Karl Rahner, 1904 - 2004 (0.100); Catequese e Discipulado (0.067); A Palavra de Deus (0.067); Moral Cristã (0.067);

Tabela 6 - Centralidade por Temática de Dossiê da Revista Perspectiva Teológica: P5-MD5 - 2010-2012, P6-MD6 - 2013-2016 e P7-MD7 - 2017-2019 (1ªED.)

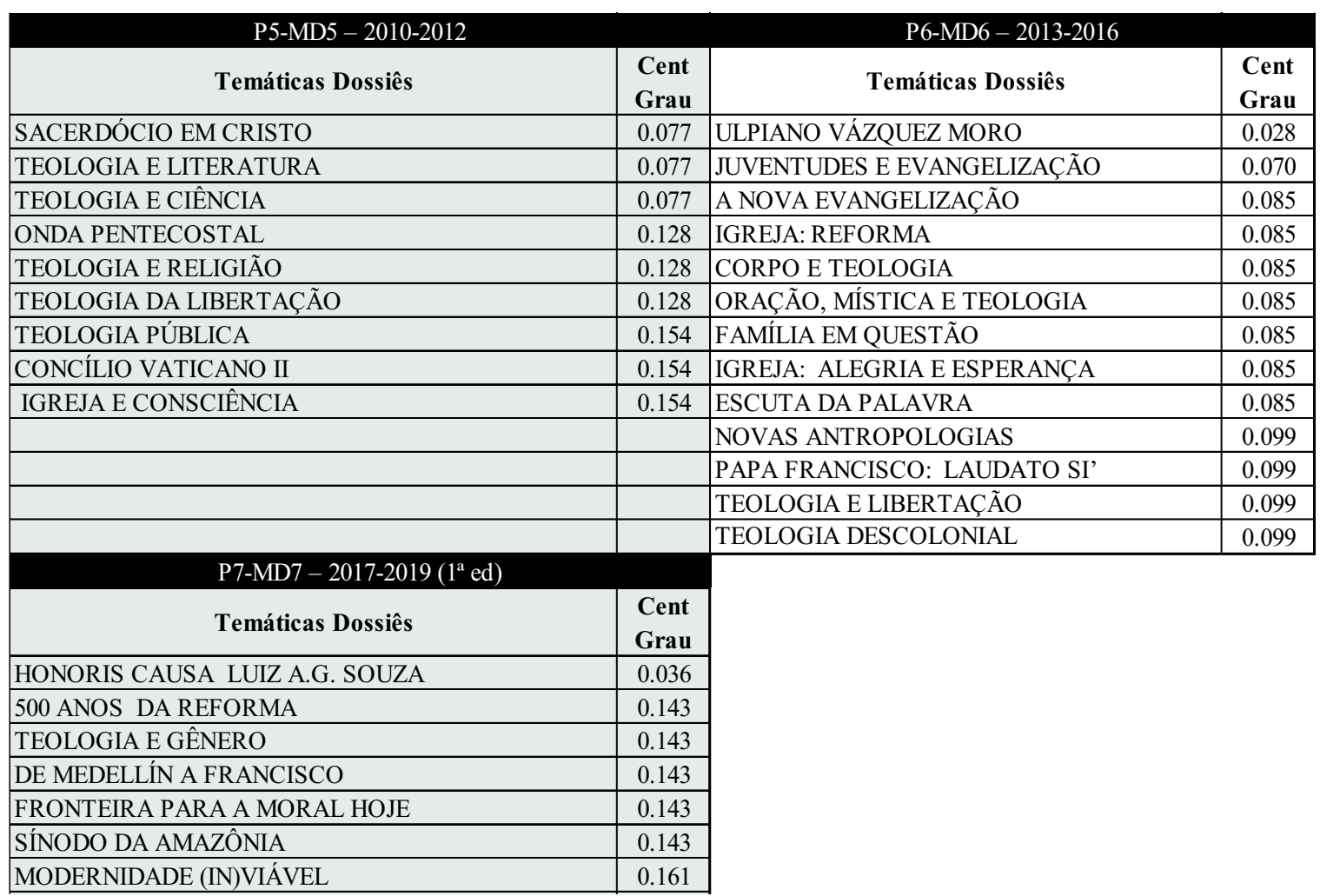

Legenda: Fonte: Elaborado pelos autores, 2019.

Na tabela 6 é possível observar que em cada período pesquisado da revista PT, as temáticas de dossiês que aparecem com maior centralidade de grau, em cada período destacam-se as com maiores centralidades de grau:

a MD5 - 2010-2012 destacam-se: Igreja e Consciência (0.154); Concílio Vaticano II (0.154); Teologia Pública (0.154); Teologia da Libertação (0.128); Teologia e Religião (0.128); Onda Pentecostal (0.128);

b MD6 - 2013-2016 destacam-se: Teologia Descolonial (0.099); Teologia e Libertação (0.099); Papa Francisco: Laudato Si' (0.099); Novas Antropologias (0.099); 
c MD7 - 2017-2019 (1ª edição) destacam-se: Grandes Problemas da Humanidade (0.161); Modernidade (In)Viável (0.161); Sínodo da Amazônia (0.143); Fronteira para a Moral Hoje (0.143); De Medellín a Francisco (0.143); Teologia e Gênero (0.143); 500 Anos Da Reforma (0.143).

O grau de centralidade por temática de dossiê tem o objetivo de identificar as temáticas mais trabalhadas em cada período pesquisado da revista PT, bem como se constituem as redes dos autores que publicaram na revista envoltos na mesma temática, destacando dessa forma, sua relevância relacional e potencial influência sobre as temáticas da área.

Tabela 7 - Análise comparada da Centralidade por Temática de Dossiê da Revista Perspectiva Teológica em relação às Áreas de Concentração da FAJE

\begin{tabular}{|c|c|c|c|c|c|c|}
\hline P1: 1969-1979 & P2: 1980-1989 & P3: 1990-1999 & P4: 2000-2009 & P5: 2010-2012 & P6: 2013-2016 & P7: 2017-2019 \\
\hline \multicolumn{7}{|c|}{ 1. Teologia da Práxis Cristã } \\
\hline \multicolumn{7}{|c|}{\begin{tabular}{l|l} 
Espiritualidade & \\
Cristã e & \\
Pluralismo & \\
Cultural e & \\
Religioso & \\
\end{tabular}} \\
\hline $\begin{array}{l}\text { Oração Cristã } \\
(0.116)\end{array}$ & \begin{tabular}{|l|}
25 anos de \\
Renovação \\
Litúrgica $(0.077)$ \\
\end{tabular} & & \begin{tabular}{|l|} 
Catequese e \\
Discipulado \\
$(0.067)$ \\
\end{tabular} & & & \\
\hline \multicolumn{7}{|c|}{\begin{tabular}{ll|l} 
Tend. Éticas & \\
Atuais & & \\
\end{tabular}} \\
\hline & $\begin{array}{l}\text { Difícil Liberdade } \\
(0.077)\end{array}$ & \begin{tabular}{|l|} 
Ética, \\
Evangelhos e \\
Culturas (0.087) \\
\end{tabular} & $\begin{array}{l}\text { Moral Cristã } \\
(0.067)\end{array}$ & \begin{tabular}{|l|} 
Igreja e \\
Consciência \\
$(0.154)$ \\
\end{tabular} & & $\begin{array}{l}\text { Fronteira para a } \\
\text { Moral Hoje } \\
(0.143) \\
\end{array}$ \\
\hline & & $\begin{array}{l}\text { Centesimus } \\
\text { Annus (0.087) }\end{array}$ & & & & \\
\hline \multicolumn{7}{|c|}{ 2. Teologia Sis te mática } \\
\hline \multicolumn{7}{|l|}{\begin{tabular}{lr|}
$\begin{array}{l}\text { Fontes } \\
\text { da }\end{array}$ & Bíblicas \\
Cristadição & \\
\end{tabular}} \\
\hline \multirow{2}{*}{\multicolumn{7}{|c|}{ 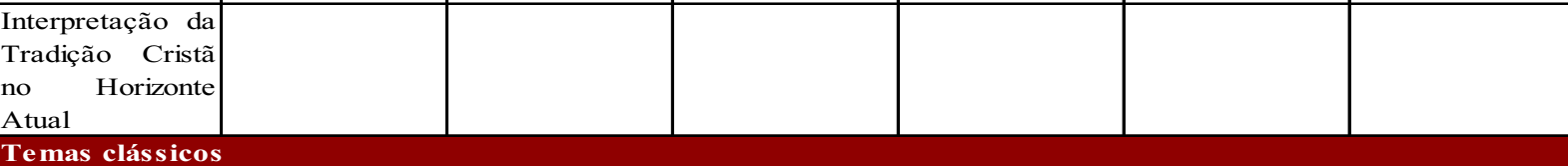 }} \\
\hline & & & & & & \\
\hline \begin{tabular}{l|} 
Cristo e o \\
Mistério da \\
Salvação (0.087) \\
\end{tabular} & $\begin{array}{l}\text { Lutero - } 500 \\
\operatorname{anos}(0.077) \\
\end{array}$ & & $\begin{array}{lcc}\text { A } & \text { Palavra } & \text { de } \\
\text { Deus }(0.067) & \end{array}$ & & & $\begin{array}{l}500 \text { Anos da } \\
\text { Reforma }(0.143)\end{array}$ \\
\hline $\begin{array}{l}\text { Perspectivas da } \\
\text { Esperança Cristã } \\
(0.159)\end{array}$ & \begin{tabular}{|l|} 
Que \\
Reconciliação? \\
$(0.077)$ \\
\end{tabular} & & & & & \\
\hline \multirow{2}{*}{\multicolumn{7}{|c|}{\begin{tabular}{l|} 
Sacerdócio \\
Ministerial \\
$(0.087)$ \\
Questões atuais
\end{tabular}}} \\
\hline & & & & & & \\
\hline $\begin{array}{l}\text { Tarefas Atuais } \\
\text { Teologia }(0.145)\end{array}$ & $\begin{array}{l}\text { Dom João R. } \\
\text { Costa (0.077) }\end{array}$ & $\begin{array}{l}\text { Repensar o } \\
\text { Cristianismo } \\
(0.239)\end{array}$ & $\begin{array}{l}\text { Karl Rahner, } \\
1904-2004 \\
(0.100)\end{array}$ & $\begin{array}{l}\text { Concílio } \\
\text { Vaticano II } \\
(0.154)\end{array}$ & $\begin{array}{l}\text { Teologia } \\
\text { Descolonial } \\
(0.099)\end{array}$ & $\begin{array}{l}\text { Grandes } \\
\text { Problemas da } \\
\text { Humanidade } \\
(0.161) \\
\end{array}$ \\
\hline $\begin{array}{l}\text { Secularização e } \\
\text { Problema de } \\
\text { Deus }(0.116)\end{array}$ & $\begin{array}{l}\text { Trinta anos } \\
\text { CNBB }(0.077)\end{array}$ & \begin{tabular}{|l} 
Volta à \\
Subjetividade? \\
$(0.109)$ \\
\end{tabular} & & $\begin{array}{l}\text { Teologia Pública } \\
(0.154)\end{array}$ & \begin{tabular}{|l|} 
Teologia e \\
Libertação \\
$(0.099)$ \\
\end{tabular} & \begin{tabular}{|l|} 
Modernidade \\
$($ In)Viável \\
$(0.161)$ \\
\end{tabular} \\
\hline \multirow[t]{3}{*}{$\begin{array}{l}\text { Vida Religiosa } \\
\text { Atual }(0.116)\end{array}$} & & \begin{tabular}{|l|}
25 Anos: Revista \\
de Teologia \\
$(0.087)$ \\
\end{tabular} & & \begin{tabular}{|l|} 
Teologia da \\
Libertação \\
$(0.128)$ \\
\end{tabular} & $\begin{array}{l}\text { Papa Francisco: } \\
\text { Laudato } S i \\
(0.099) \\
\end{array}$ & \begin{tabular}{|l|} 
Sínodo da \\
Amazônia \\
$(0.143)$ \\
\end{tabular} \\
\hline & & \begin{tabular}{|l|} 
Socialismo e \\
Teologia $(0.087)$ \\
\end{tabular} & & \begin{tabular}{|l|} 
Teologia e \\
Religião $(0.128)$ \\
\end{tabular} & $\begin{array}{l}\text { Novas } \\
\text { Antropologias }\end{array}$ & $\begin{array}{l}\text { De Medellín a } \\
\text { Francisco } \\
\end{array}$ \\
\hline & & $\begin{array}{l}\text { Uma Nova } \\
\text { Evangelização? } \\
(0.087)\end{array}$ & & \begin{tabular}{|l} 
Onda \\
Pentecostal \\
$(0.128)$ \\
\end{tabular} & & $\begin{array}{l}\text { Teologia e } \\
\text { Gênero }(0.143)\end{array}$ \\
\hline
\end{tabular}

Legenda: Fonte: Elaborado pelos autores, 2019. 


\section{Considerações finais}

Um periódico científico presta serviço à comunidade acadêmica, e a análise do seu desempenho pretende dar visibilidade às suas características principais a fim de melhor identificar seu perfil e sua contribuição. Também a análise de redes para a área acadêmica revela associações e perspectivas, até então, não observadas sem o auxílio desta metodologia de pesquisa. Neste intuito o presente trabalho procurou, através do método de bibliometria e sociometria analisar o comportamento e desempenho deste importante periódico para a comunidade acadêmica brasileira de teólogos/as e cientistas da religião.

A Perspectiva Teológica é o primeiro periódico científico vinculado a um Programa de Pós-Graduação em Teologia de confissão católica, e o segundo mais antigo do país.

Verifica-se em sua trajetória, um movimento de uma temática mais dispersiva nas duas primeiras décadas, pela maior presença de artigos com temas livres (cf. Figura 4 e 5; Tabela 4, P1 1969-1979: 0,232; P2 1980-1989: $0,327)$ para a consolidação da prática de dossiês, podendo assim melhor identificar um perfil editorial da mesma. No que diz respeito ainda ao desempenho editorial, se constata que há uma maior consolidação da periodicidade quadrimestral na segunda década de sua existência, porém um efetivo crescimento se nota somente na última década (2011), em que passa a ter mais de 15 artigos por volume anual, em movimento crescente, fator que pode estar atrelado ao aumento de classificação no Qualis periódicos da CAPES.

Apesar de ter 276 autores que publicaram no periódico, entre os 10 principais colaboradores, 9 são jesuítas, e entre os 20 principais colaboradores, apenas 4 não são da instituição, e esse número reduziria se considerar os colaboradores diretos da mesma. Ademais, o perfil autoral não é configurador de redes, havendo um baixo índice de coautoria (Figura 1, P2 e P4; Figura 2, P5-P7, com destaque para P6; Figura 3; Tabela 2).

Dito de outro modo, os elos relacionais das redes de pesquisa se configuram por temáticas, que serão analisadas em perspectiva horizontal (desenvolvimento histórico) e vertical (maior centralidade de grau).

É interessante considerar na análise do desempenho da PT, que a ampliação temática é um momento de expansão possível da rede, que vai se consolidando com a presença de vários atores, e progressiva discussão destes autores em temas que se desdobram em outros correlatos, indicando assim como perfil do periódico os temas com maior incidência cronológica. Uma expansão que não se consolida em rede indica uma dispersão temática e descontinuidades, indicando a presença de temas episódicos no periódico, que variam em quantidade. 
Isto posto, em uma análise horizontal, o desempenho da PT em P1 (19691979) indica uma tendência de consolidação, dada a simetria entre as temáticas e os autores envolvidos ao redor de questões relacionadas a atualidade (3 dossiês), Teologia da Libertação (2 dossiês) e Espiritualidade (2 dossiês). Ao analisar o desenvolvimento cronológico das publicações da Perspectiva Teológica, pode-se verificar no P1 que a temática que teve maior incidência de nucleação, com maior número de autores foi relacionada à temática da Esperança Cristã (0,159; Tabela 4, Figura 4), porém é um tema episódico, pois não encontrou continuidade na linha temporal do periódico que indicasse a atenção para questões correlacionadas, como por exemplo a escatologia, que não é ausente no periódico, mas também não é uma área de destaque. Já a segunda temática, Tarefas atuais da Teologia $(0,145$; Tabela 4, Figura 4), indica um primeiro movimento em direção a temática da teologia contemporânea, que se torna recorrente ao longo da cronologia topográfica do periódico, ainda que com índices variados de centralidade (P2: Teologia possível, 0,058; P3: Teologia e Método, 0,043; Desafios para a Teologia, 0,065; P4: O Caminho da Teologia, 0,050; Teologia Pública, 0,154; Teologia Descolonial, 0,099).

O mesmo aconteceu com temáticas relacionadas à Teologia da Libertação (P1: Teologia da Libertação, 0,058; Fazer Teologia na América Latina, 0,072; P2: Modernidade e Libertação 0,058; P3: Medellín, Puebla 0,043; Lembrar dos Pobres (Gl 2,10) 0,065; Jesus, o Evangelho e os Pobres 0,065; CEBs: Vida e Esperança 0,065; P4: Cristianismo na América Latina 0,050; P5: Teologia da Libertação 0,128; P6: Teologia e Libertação 0,99), com destaque para P3 que publica 3 edições, pertinente ao contexto de neo-ortodoxia e as tensões pontificado de João Paulo II e o tempo de Guerra Fria. Nesse caso, considerando a Teologia da Libertação $(8,2 \%)$ com um tema privilegiado da Teologia contemporânea (6\%), esta tendência resulta em $14 \%$ das temáticas da PT.

Entretanto, das 3 temáticas com maior índice de centralidade em P1, a preocupação com a atualidade é a que mais se destaca e se consolida na PT podendo se afirmar como um perfil característico do periódico a preocupação com problemas contemporâneos (Missão na Atualidade 0,058; Missão e Igreja Hoje 0,072 ; Secularização e o Problema de Deus 0,116; Tarefas atuais da Teologia 0,145 ${ }^{10}$; P3: Juventude: Protesto ou Acomodação 0,065; Meio Ambiente e Desenvolvimento 0,065; Evangelizar a Cidade Moderna 0,065; Fé cristã do Novo Milênio 0,065; Socialismo e Teologia 0,087; Volta a subjetividade? 0,109; Repensar o Cristianismo 0,239; P4:

\footnotetext{
${ }^{9}$ Algumas edições não apresentaram um tema explicitamente, mas se apresentaram no Editorial como um dossiê, de onde foi extraído a temática analisada.

${ }^{10}$ Alguns temas são híbridos podendo serem classificados em mais de uma temática.

${ }^{11}$ Para esta linha distinguimos as temáticas em "temas clássicos" e "questões atuais" de Teologia Sistemática.
} 
Minorias que são Maiorias 0,050; Evangelização e Mídia 0,050; P6: Novas Antropologias 0,99; P7: Teologia e Gênero 0,143; Modernidade (In)viável 0,161; Grandes Problemas da Humanidade 0,161). Corrobora para isso o fato de que o tema gerador de maior centralidade é de "Repensar o Cristianismo" (0,239) em P3 (1990-1999). Tal tendência é responsável por $12,8 \%$ das temáticas da PT.

Outra tendência característica, que fica mais forte à partir de P2 (1980-1989) é a Eclesiologia em diversas abordagens, especialmente por ocasião do Sínodo de 1985 (P1: Missão da Igreja Hoje 0,072; Concílio Vaticano I 0,072; P2: Igreja na "Nova República" 0,058; Sínodo 85 0,058; Sínodo: Mistério e Comunhão 0,058; Igreja diante da Constituinte 0,058; Colegialidade e Pastoral 0,058; Centralização ou Descentralização 0,058; Trinta Anos CNBB $(0,077)$; P3: Medellín e Puebla 0,043; 30 Anos depois do Concílio Vaticano II 0,065; CEBs: Vida e Esperança 0,065; Igreja em Belo Horizonte 0,065; P4: O Grande Jubileu 0,050; Episcopado 0,050; Vaticano II: 40 anos depois 0,050; Rumo a Aparecida: V CELAM 0,050; Depois de Aparecida 0,050; P5: Concílio Vaticano II 0,154; Igreja e Consciência 0,154; P6: A Nova Evangelização 0,085; Igreja e Reforma 0,085; Igreja: Alegria e Esperança 0,085; Papa Francisco: Laudato si'0,099; P7: De Medellín à Francisco 0,143; Sínodo da Amazônia 0,143). Tal tendência é responsável por 19,5\% das temáticas da PT.

Para uma análise vertical, procurou identificar as temáticas com maior índice de centralidade, ou seja, temáticas com capacidade de nucleação de rede, estabelecendo uma comparação com as áreas de concentração do Programa de Pós-Graduação em Teologia da FAJE, e suas respectivas linhas de pesquisa, a saber:

1) Teologia da Práxis Cristã

1.1) Espiritualidade Cristã e Pluralismo Cultural e Religioso

1.2) Tendências Éticas Atuais

2) Teologia Sistemática

2.1. Fontes Bíblicas da Tradição Cristã

2.2. Interpretação da Tradição Cristã no Horizonte Atual ${ }^{11}$

Em P1 (1969-1979) se destacam as temáticas relacionadas à Teologia Sistemática, com maior ênfase a questões atuais (Tarefas Atuais Teologia 0.145; Secularização e Problema de Deus 0.116; Vida Religiosa Atual 0.116) seguido de temas clássicos (Perspectivas da Esperança Cristã 0.159; Cristo e o Mistério da Salvação 0.087; Sacerdócio Ministerial 0.087). Em P2 (19801989) permanece a ênfase em Teologia Sistemática, divididas em questões atuais (Dom João R. Costa 0.077; Trinta anos CNBB 0.077) e temas clássicos (Lutero - 500 anos 0.077; Que Reconciliação? 0.077). Em P3 (1990-1999) há uma predominância majoritária na Área de Teologia Sistemática no que diz respeito às questões atuais (Repensar o Cristianismo 0.239; Volta 
à Subjetividade? 0.109; 25 Anos: Revista de Teologia 0.087; Socialismo e Teologia 0.087; Uma Nova Evangelização? 0.087). Em P4 (2000-2009) há um equilíbrio entre temas da Teologia da Práxis Cristã (Catequese e Discipulado 0.067; Moral Cristã 0.067) e temas da Teologia Sistemática (Karl Rahner, 1904 - 2004 0.100; A Palavra de Deus 0.067), com uma pequena diferença de maior incidência nesta última $(0,167$ em reação à 0,134$)$. Em P5 (2010-2012) há uma predominância majoritária em questões atuais de Teologia Sistemática (Concílio Vaticano II 0.154; Teologia Pública 0.154; Teologia da Libertação 0.128; Teologia e Religião 0.128; Onda Pentecostal 0.128) e em P6 (2013-2016) a mesma tendência se repete (Teologia Descolonial 0.099; Teologia e Libertação 0.099; Papa Francisco: Laudato Si' 0.099; Novas Antropologias 0.099) e apesar da presença de um tema com maior centralidade na Teologia da Práxis Cristã (Fronteira para a Moral Hoje 0.143), permanece a predominância de questões atuais de Teologia Sistemática (Grandes Problemas da Humanidade 0.161; Modernidade (In)Viável 0.161; Sínodo da Amazônia 0.143; De Medellín a Francisco 0.143; Teologia e Gênero 0.143) em relação à temas clássicos (500 Anos da Reforma 0.143).

Do ponto de vista das temáticas com maior capacidade de nucleação temática, verifica-se uma clara tendência de um perfil de teologia sistemática em questões atuais, havendo uma assimetria em relação às áreas. E mesmo entre as linhas, como é o caso das Fontes Bíblicas da Tradição Cristã, não figuram entre os temas de maior centralidade, bem como possuem pouca representatividade (1,5\% das temáticas da PT, somente em P4: 2000-2009).

Para uma análise de uma tendência geral da evolução do desempenho da PT, há uma relação relativamente simétrica em P1: 1969-1979, entre a abrangência temática e a nucleação de autores (Figura 4, não considerando a Temática Livre) que começa a se alterar em P2: 1980-1989, na medida em que há uma ligeira ampliação temática, e uma menor nucleação e diversidade de autores, o que sugere uma presença mais expressiva da rede de autores jesuítas (Figura 5, não considerando a Temática Livre). Curiosamente, a significativa presença de autores jesuítas não resulta em edições temáticas de grandes autores jesuítas, restringindo-se a 3 grandes nomes em 50 anos de existência da PT (Henri de Lubac 0,038; Karl Rahner 0,038; 0,100; Ulpiano Vázquez Moro 0,028). Em P3: 1990-1999 há uma maior abrangência temática assimétrica, na medida em que não houve aumento expressivo de autores, apesar de uma maior nucleação de autores externos (Figura 6). Em P4: 2000-2009 permanece a assimetria de abrangência temática e nucleações menores (Figura 7). Em P5: 2010-2012 há uma maior nucleação, porém com apenas 2 pontos de conexão entre os núcleos (Figura 8), que se altera em P6: 2013-2016 para 6 pontos (Figura 9), porém em P7: 2017-2019 recua em 4 pontos de conexão.

Nos sociogramas gerais pode se evidenciar a incidência de menor variedade de autores, que confirma a Tabela 1 sobre a presença majoritária de 
jesuítas, nas quatro primeiras décadas da PT (Figuras 11-14). A partir de 2010 inicia a tendência de ampliação de autores externos. Esta constatação pode ser resultado de políticas de indução da CAPES para redução de endogenia. Entretanto as temáticas demonstram um movimento crescente de P6 (maior incidência de 0,085 por temática, 6-7 autores) para P7 (maior incidência de 0,143 por temática, 8-9 autores). Todavia, a aparente dispersão não se caracteriza como distintiva, na medida em que há uma convergência temática que consolida duas grandes características do periódico, de temas de atualidade $(12,5 \%)$ e de teologia contemporânea $(14,2 \%)$ e temas de eclesiologia $(19,5 \%)$, elementos expressivos $(46,2 \%)$ da perspectiva teológica do periódico, a fronteira e o sentir cum Ecclesia, em um movimento crescente de incorporação de novos autores. Deste modo, se desloca de um debate de temas de fronteira entre a comunidade acadêmica institucional para um universo mais amplo. Ademais, esses dois elementos recorrentes em questões de atualidade e de eclesiologia acabam por consolidar em uma série histórica a expansão temática, pois operam como horizontes norteadores das escolhas editoriais, reduzindo a dispersão temática na medida em que a diferença vai se agrupando nesses dois eixos. Por fim, um aparente desafio é a representação das Áreas de concentração do Programa de Teologia com suas respectivas linhas no periódico.

\section{Referências}

ABDALLA, K. G. M. Z. et al. Pensando Contabilidade: um estudo bibliométrico e sociométrico da produção científica da Revista Pensar Contábil no período de 2006-2012. Pensar Contábil, Rio de Janeiro, v. 16, n. 59, p. 30 - 38, jan./abr. 2014.

AIRES et al. Relationship and Performance: Sociometric and Bibliometric Study of the Scientific Production of the Graduate Program in Accounting at Unisinos. REBRAE, Curitiba, v. 9, n. 2, p. 164-181, may./aug. 2016.

ARAUJO, C. A. Bibliometria: evolução história e questões atuais. Em Questão, Porto Alegre, v. 12, n. 1, p. 11-32, jan./jun. 2006.

BECKER, B. K; BUARQUE, C; SACHS, I. Dilemas e desafios do desenvolvimento sustentável no Brasil. Rio de Janeiro: Garamond, 2007.

BORGATTI, S.P.; EVERETT, M.G.; FREEMAN, L.C. Ucinet for Windows: Software for Social Network Analysis. Harvard, MA: Analytic Technologies, 2002.

CAMPOS, M. Conceitos atuais em bibliometria. Arquivos Brasileiros de Oftalmologia, São Paulo, v. 66, n.1, p. 18-21, 2003.

CRUZ, J. A. W. A União faz a força: a cooperação como estratégia de sobrevivência organizacional. Curitiba: Protexto Editora Zamoner Ltda., 2007.

A relação entre estrutura de redes sociais e desempenho: um estudo de caso de associações de carrinheiros no Paraná - Brasil. 126 f. Tese de Doutorado em Administração. Programa de Pós-Graduação em Administração. Pontifícia Universidade Católica do Paraná, Curitiba, 2012. 
; MARTINS, T. S.; AUGUSTO, P. O. M. (Org). Redes sociais e organizacionais em Administração. Curitiba: Juruá, 2008.

MARTINS, T. S.; MARTINS, R. R. R.; KATO, H. T. A Network Temporal Analysis: a series from 2007 to 2009 of a Brazilian Renewable Materials Network. Chicago: Strategic Management Society, 2011.

CRUZ, J. A. W.; QUANDT, C. O.; MARTINS, T. S. A Cooperação em redes como forma de promoção de desenvolvimento. Revista Alcance, v. 15, n. 2, 2008.

; QUANDT, C. O.; MARTINS, T. S.; KATO, H. T.; MARTINS, R. R. R. How Does The Structure Of Social Networks Affect The Performance Of Its Actors? A case Study in the Brazilian Context. Massachussets: Academy of Management, 2013.

DEGENNE, A.; FORSÉ, M. Introducing Social Networks. London: Sage Publications, 1999.

DOS SANTOS, R. M. N.; KABASHI, N. Y.: Bibliometria, cientrometrie, infometria: conceitos e aplicações. Pes. Bras. Ci, Inf, Brasília, v. 2, n. 1, p. 155 - 172, jan./dez., 2009.

FREEMAN, L. C. Centrality in Social Networks: Conceptual Clarification. Lausanne. Social Networks, 1979. v. 1.

GRANOVETTER, M. S.; SWEDBERG, R. The Sociology of Economic Life. Cambrigde: Westview, 2001.

HUTT, M. D. et al. Case study defining the social network of a strategic alliance. Sloan Management Review, winter, jan, 2000.

JOURNAL DES SAVANTS. Paris: Académie des inscriptions et belles-lettres. Disponible en: <https://www.aibl.fr/publications/collections/journal-des-savants/?lang=fr >. Accès en: 31 août 2019.

KUHLMANN JR, M. Publicação em periódicos científicos: ética, qualidade e avaliação da pesquisa. Cadernos de Pesquisa, São Paulo, v. 44, n. 151. p. 16-32, jan./mar. 2014.

LEAVITT, H. Some effects of Certain Communication Patterns on Group Performance. Journal of Abnormal and Social Psychology, 1951.

LORRAIN, F.; WHITE, H. C. Structural Equivalence of Individuals in Social Networks. Journal of Mathematical Sociology, v. 1, n. 1, 1971.

LUITZ, M. P.; REBELATO, M. G. Avaliação do desempenho organizacional. In: ASSOCIAÇÃO BRASILEIRA DE ENGENHARIA DE PRODUÇÃO, 23, 2003. Ouro Preto. Anais... Ouro Preto: ENEGEP, 2003.

MIRANDA, D. B.; PEREIRA, M. N. F. O periódico científico como veículo de comunicação: uma revisão de literatura. Ciência da Informação, Brasília, v. 25, n. 3. p. 375-382, dez. 1996.

MIZRUCHI, M. S. Análise de redes sociais: avanços recentes e controvérsias atuais. Revista de Administração de Empresas, v. 46, n. 3, p. 10-15, jul./set. 2006.

OLAVE, M. E.; AMATO NETO, J. A. Redes de cooperação produtiva: uma estratégia de competitividade e sobrevivência para pequenas e médias empresas. Gestão $\mathcal{E}$ Produção, v. 8, n. 3, dez., 2001. 
OLIVEIRA, J. C. Estudo bibliométrico das publicações de custos em enfermagem no período de 1966 a 2000. 2001. Dissertação (Mestrado em Enfermagem) - Escola de Enfermagem, Universidade de São Paulo, São Paulo, 2001.

PÁDUA, E. M. M. de. Metodologia da pesquisa: abordagem teórico-prática. 10.ed. Campinas: Papirus, 2004.

PIEPER, F. Aspectos históricos e epistemológicos da ciência da religião no Brasil: um estudo de caso. Numen, Revista de Estudos e Pesquisa da Religião, Juiz de Fora, v. 21, n. 2. p. 232-1291, jul./dez. 2018a. Disponível em: <https://periodicos.ufjf. br/index.php/numen/article/view/22159/14804>. Acesso em: 23 ago. 2019.

PHILOSOPHICAL TRANSACTIONS. London: The Royal Society Publishing. Available in: < https://royalsocietypublishing.org/journal/rstl>. Access: 31 Aug. 2019.

POWELL, W. W.; SMITT-DOERR, L. Networks and economic life. In: SMELSER N. J.; SWEDBERG, R. The Handbook of Economic Sociology. New Jersey: Princeton, 1994.

ROCHA, D. T. et al. Relacionamento e Desempenho: Estudo bibliométrico e sociométrico da produção científica do programa de mestrado em ciências contábeis da FURB. Revista Pensar Contábil, v. 15, n. 58, 2014.

SCOTT, J. Social Network Aanalysis: a Handbook. 2nd ed. London: Sage, 2000.

SIMSEK, Z.; LUBATKIN, M. H.; FLOYD S. W. Inter-firm networks and entrepreneurial behavior: a structural embeddedness perspective. Journal of Management, 2003.

STUMPF, I. R. C. Passado e futuro das revistas científicas. Ciência da Informação, Brasília, v. 25, n. 3, 1996. [s. p.]. Disponível em: <http://revista.ibict.br/ciinf/article/ view/637/641>. Acesso em: 10 de mar. 2009.

USARSKI, F. A construção do diálogo: o Concílio Vaticano II e as religiões. São Paulo: Paulinas, 2018.

VAN AKEN, J. E.; WEGGEMAN, M. P. Managing Learning in Informal Innovation Networks: Overcoming the Daphne-Dilemma. RED Management, v. 30, n. 2, p. 139-149, 2000.

VANTI, N. A. P. Da bibliometria à webometria: uma exploração conceitual dos mecanismos utilizados para medir o registro da informação e da difusão do conhecimento. Ciência da Informação, Brasília, v. 31, n. 2, p. 152-162, maio/ago. 2002.

WALTER, S. A.; SILVA, E. D. da. Visão Baseada em Recursos: um Estudo Bibliométrico e de Redes Sociais da Produção Científica da Área de Estratégia do EnANPAD 1997-2007. In: ENCONTRO DA ASSOCIAÇÃO NACIONAL DE PROGRAMAS DE PÓS-GRADUAÇÃO EM ADMINISTRAÇÃ̃O, 32, 2008. Rio de Janeiro. Anais... Rio de Janeiro: ANPAD, 2008.

WASSERMAN, S; FAUST, K. Social Network Analysis: Methods and Applications. Cambridge: Cambridge University Press, 1994.

Wellman, B. Structural Analysis: from Method and Metaphor to Theory and Substance. In B. Wellman \& S. D., 1988.

WELLMAN, B. An Egocentric Tale. Social Networks, 1993. 
Alex Villas Boas é doutor em Teologia pela PUCRIO - 2013. Professor Livre docente na Área de Teologia pela PUC SP. Investigador principal e coordenador científico do Centro de Investigação em Teologia e Estudos de Religião da Universidade Católica Portuguesa (UCP CITER). Professor no Programa de Pós-Graduação em Teologia da PUC PR. Orcid.org/00000003-2779-1108. Email: alex.boas@pucpr.br

Contribuição no artigo: coordenador do projeto de pesquisa de Mapeamento da Produção da Área de Ciências da Religião e Teologia, do qual o presente artigo é fruto, estruturação em parceria do esboço, construção de instrumental teórico para análise e sistematização dos dados.

Endereço: CITER UCP, Palma de Cima

1649-023 Lisboa, Portugal

Andréia Cristina Serrato doutora em Teologia pela PUCRIO - 2015. Professora no Curso de Teologia da PUCPR. Orcid.org/0000-0003-0150-0413. Email: andreia.serrato@pucpr.br.

Contribuição no artigo: vice-coordenadora do projeto de pesquisa de Mapeamento da Produção da Área de Ciências da Religião e Teologia, acompanhamento do levantamento de dados, coordenação de recursos humanos, construção de instrumental teórico para análise e sistematização dos dados.

Endereço: Rua Mato Grosso, 1286, Ferraria 83608240 Campo Largo, Paraná

Alaís Daiane Zdziarski é mestre em Administração pela PUCPR (2016 - 2018). Consultora em Pesquisas e Softwares de Pesquisas. Pesquisadora em grupo de pesquisa do PPGT da PUCPR, atuando com análise de dados de redes sociais. Orcid.org/0000-0002-5598-9931. Email: alaisdaiane@gmail.com.

Contribuição no artigo: definição de método de coleta de dados, análise dos dados em software, análise quantitativa de dados, descrição das análises de dados quantitativos, contribuição no referencial teórico, auxílio na revisão geral do artigo.

Endereço: Av. Silva Jardim, nº 1762, Ap 63, Água Verde 80240-020 Curitiba, Paraná

June Alisson Westarb Cruz é doutor em Administração pela PUCPR - 2012. Professor do Programa de Pós-Graduação em Administração da PUCPR. Orcid.org/0000-0002-4183-9983. Email: june.cruz@pucpr.br

Contribuição no artigo: definição de método de coleta de dados, análise dos dados em software, análise quantitativa de dados, descrição das análises de dados quantitativos, contribuição no referencial teórico, auxílio na revisão geral do artigo.

Endereço: Rua Rio Iriri, no 17, casa 13, Bairro Alto

82840310 Curitiba, Paraná

O presente trabalho de análise dos dados foi realizado pelos discentes que participam do Grupo de Pesquisa em Teopatodiceia: Espiritualidade, Cultura e Práxis (CNPq) e que atuam no projeto de Mapeamento da Área de Ciências da Religião e Teologia (2017- ). Estão envolvidos os discentes do Programa de Pós-Graduação: Allan de Macedo Simões, Valdecir Ferreira (PPG em Teologia); Aline Vicentim Villas Boas (PPG de Educação), os discentes de PIBIC Daniel Liberato Lemes, Edi Carlos Cardoso dos Santos, Elis Regina Antonia Maletski, Emanuel Eduardo Ferreira Calão, Eva Gislane Barbosa, Fabiana Torres Xavier, Joseliane Anacleto Stanger, Michel Eriton Quintas, Silvana de Oliveira Sitarz, Tiago Silva da Rosa. 